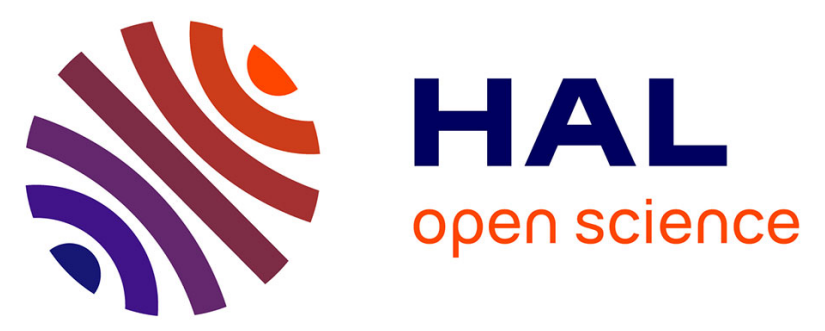

\title{
Chlorotrimethylsilane and Sodium Iodide: A Useful Combination for the Regioselective Deoxygenation of Arylalkyl- $\alpha$-Diketones
}

Ling-Zhi Yuan, Guangkuan Zhao, Abdallah Hamze, Mouad Alami, Olivier Provot

\section{To cite this version:}

Ling-Zhi Yuan, Guangkuan Zhao, Abdallah Hamze, Mouad Alami, Olivier Provot. Chlorotrimethylsilane and Sodium Iodide: A Useful Combination for the Regioselective Deoxygenation of Arylalkyl- $\alpha$-Diketones. Advanced Synthesis and Catalysis, 2017, 359 (15), pp.2682-2691. 10.1002/adsc.201700276 . hal-02394293

\section{HAL Id: hal-02394293 \\ https://hal.science/hal-02394293}

Submitted on 4 Dec 2019

HAL is a multi-disciplinary open access archive for the deposit and dissemination of scientific research documents, whether they are published or not. The documents may come from teaching and research institutions in France or abroad, or from public or private research centers.
L'archive ouverte pluridisciplinaire HAL, est destinée au dépôt et à la diffusion de documents scientifiques de niveau recherche, publiés ou non, émanant des établissements d'enseignement et de recherche français ou étrangers, des laboratoires publics ou privés. 
DOI: 10.1002/adsc.201((will be filled in by the editorial staff))

\title{
Chlorotrimethylsilane and Sodium Iodide: A Useful Combination for the Regioselective Deoxygenation of Arylalkyl- $\alpha$-Diketones
}

\author{
Ling-Zhi Yuan, Guangkuan Zhao, Abdallah Hamze, Mouad Alami* and Olivier Provot*
}

BioCIS, Univ. Paris-Sud, CNRS, Equipe Labellisée Ligue Contre le Cancer, Université Paris-Saclay, Châtenay-Malabry, (France) Fax: (+33) 1 46-83-58-87, E-mail: olivier.provot@u-psud.fr or mouad.alami@u-psud.fr

Received: ((will be filled in by the editorial staff))

Supporting information for this article is available on the WWW under http://dx.doi.org/10.1002/adsc.201\#\#\#\#\#\#.((Please delete if not appropriate))

\begin{abstract}
An efficient regioselective deoxygenation of arylalkyl-1,2diketones by the couple trimethylsilylchloride/sodium iodide has been reported. In all cases, the deoxygenation takes place on the carbonyl group $(\mathrm{C} \alpha=\mathrm{O})$ proximal to the aromatic ring in methylene chloride at room temperature in good yields, furnishing a series of variously functionalized alkylbenzylketones. A large range of functional groups were well tolerated on the ortho-, meta- and para-positions by this mild process regardless of their electronic effects,
\end{abstract}

demonstrating the general character of the present methodology. The trimethylsilylchloride/sodium iodide reducing process was also successfully applied to reduce $\alpha$ ketoacid and $\alpha$-ketoester substrates.

Keywords: Deoxygenation, 1,2-diketone, 1,2-ketoester, chlorotrimethylsilane, sodium iodide, selectivity.

\section{Introduction}

The combination of chlorotrimethylsilane (TMSCl) with sodium iodide (NaI) has been used as a versatile reagent association in a variety of chemical transformations as the cleavage of ethers, esters, lactones, carbamates, and for the conversion of alcohols into iodide derivatives. ${ }^{[1]}$ Moreover, the usefulness of the TMSCl/NaI combination was shown acting as a reducing reagent for example, in the deoxygenation of sulfoxides to sulfides. ${ }^{[2]}$ Very recently, we demonstrated for the first time that this combination was very efficient to regioselectively reduced a large variety of unsymmetrical 1,2-diaryldiketones 1 (benzils) to provide, at room temperature in $\mathrm{CH}_{2} \mathrm{Cl}_{2}$, a series of $\alpha$-deoxybenzoins 2 ( $\alpha$-DOBs) with good to excellent yields (Scheme 1). ${ }^{[3]}$ In this work, we have demonstrated that the reducing species in $\mathrm{CH}_{2} \mathrm{Cl}_{2}$ was unequivocally the equimolar combination of TMSCl with $\mathrm{NaI}$ rather than TMSI (which was not generated in situ ${ }^{[4]}$ in $\mathrm{CH}_{2} \mathrm{Cl}_{2}$ ) or $\mathrm{HI}$ (possibly generated between the couple TMSCl/NaI and traces of water present in $\mathrm{CH}_{2} \mathrm{Cl}_{2}$ ). We have also showed that a total $\alpha$-regioselectivity was observed for a variety of non-symmetrical benzils $\mathbf{1}$ having necessarily electron-donating groups (e.g., $\mathrm{OMe}, \mathrm{OH}$,
$\mathrm{SMe}, \mathrm{NH}_{2}$, etc) on the ortho- and/or on para-positions. Here we extend these studies to the deoxygenation of various arylalkyl- $\alpha$-diketones $\mathbf{3}$ by the couple $\mathrm{TMSCl} / \mathrm{NaI}$ in view of preparing rapidly a small library of alkylbenzylketones $\mathbf{4}$ of biological interest, ${ }^{[5]}$ or as useful intermediates for chemical transformations. ${ }^{[6]}$ To our knowledge, the deoxygenation of arylalkyl- $\alpha$-diketones was only studied with 1-phenylpropane-1,2-dione (3a). ${ }^{[7]}$ Stephenson $^{[7 a]}$ reported the deoxygenation of $\mathbf{3 a}$ through a two-steps sequence using trimethylphosphite (yield not given) followed by a quantitative hydrogenation using $\mathrm{H}_{2}$ and $\mathrm{PtO}_{2}$. Several years later, Kamochi, ${ }^{[7 b]}$ reported the deoxygenation of 3a using an excess of $\mathrm{SmI}_{2}$ (8 equiv) which provided only $7 \%$ of $\mathbf{4 a}$.

From a synthetic point of view, the development of a general and simple method for the regioselective deoxygenation of arylalkyl- $\alpha$-diketones $\mathbf{3}$ into alkylbenzylketones $\mathbf{4}$ is still desired. Herein we disclose our success on the development of such a selective and easy to handle mild protocol using the $\mathrm{TMSCl} / \mathrm{NaI}$ combination in methylene chloride. We found that the total regioselective reduction of substituted arylalkyl- $\alpha$-diketones of type $\mathbf{3}$ occurred selectively regardless the electronic nature of the 
Scheme 1. TMSCl/NaI promoted the deoxygenation of $\alpha$-diketones.

Our previous work ref. 3<smiles>[R]c1ccc(C(=O)C(=O)c2ccc(F)cc2)c([R])c1</smiles>

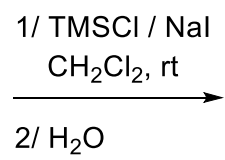

$2 / \mathrm{H}_{2} \mathrm{O}$

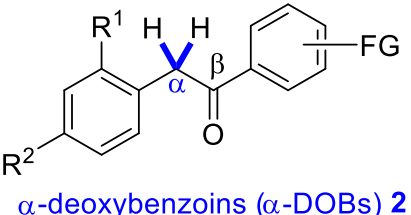

$\mathrm{R}^{1}$ or $\mathrm{R}^{2}=\mathrm{Me}, \mathrm{OMe}, \mathrm{OH}, \mathrm{SMe}, \mathrm{NH}_{2}, \mathrm{Ar}, \ldots \quad \mathrm{FG}=$ Functional Groups

This work:

R= $=\mathrm{CN}, \mathrm{NO}_{2}, \mathrm{Br}, \mathrm{CO}_{2} \mathrm{Me}, \mathrm{OMe}, \mathrm{SMe}, \mathrm{NHAc}, \ldots \quad$ alkylbenzylketones 4

substituent on the aromatic ring (electron-withdrawing or electron-donating).

\section{Results and Discussion}

At the beginning of the present work, we first studied the deoxygenation of 1-phenylpropanedione 3a as a model substrate in the presence of $\mathrm{TMSCl}$ (5 equiv) and $\mathrm{NaI}$ (5 equiv) in $\mathrm{CH}_{2} \mathrm{Cl}_{2}$ at $\mathrm{rt}$ (Table 1 , entry 1 ). We were pleased to observe that after 24 hours of reaction, the $\alpha$-carbonyl function $(\mathrm{C} \alpha=\mathrm{O})$ of $\mathbf{3 a}$, closed to the aromatic ring, was totally reduced to furnish 1-phenylpropan-2-one 4a with a good yield of $80 \%$, and with no trace of its $\beta$-regioisomer propiophenone. This result was particularly interesting and could be advantageously compared with those obtained with the deoxygenation of benzil derivatives developed in our group: ${ }^{[3]}(i)$ the replacement of a phenyl group by a methyl substituent facilitates the reducing process as $\mathbf{3 a}$ was reduced in only $24 \mathrm{~h}$ at $\mathrm{rt}$ in $\mathrm{CH}_{2} \mathrm{Cl}_{2}$, whereas the deoxygenation of $\mathrm{PhCOCOPh}$ was incomplete after $72 \mathrm{~h}$ of stirring in $\mathrm{CH}_{2} \mathrm{Cl}_{2}$ at $\mathrm{rt} ;{ }^{[8]}$ (ii) on the contrary to benzil derivatives, the reducing process occurred regioselectively on the C $\alpha$ of $\mathbf{3 a}$ but without the need of an electron-donating group on the ortho- or on the para-position of the aromatic ring. This result was confirmed with 1-phenyloctane-1,2dione $\mathbf{3 b}$, which was also regioselectively reduced into 1-phenyloctan-2-one $\mathbf{4 b}$ in the presence of the $\mathrm{TMSCl} / \mathrm{NaI}$ combination (90\%, entry 2). These two results prompted us to evaluate this reducing process with electron-poor arylalkyl- $\alpha$-diketones $3 \mathbf{c}-\mathbf{n}$ (entries $3-14)$ and with electron rich arylalkyl- $\alpha$-diketones 3o$\mathbf{z}$ (entries 15-26), easily available from the $\mathrm{PdI}_{2} / \mathrm{DMSO}$ oxidation of the corresponding arylalkylalkynes. ${ }^{[9,10]}$ We were very delighted to observe that the deoxygenation process occurred well with $\alpha$-diketone $3 \mathbf{c}$ having a $p$ - $\mathrm{NO}_{2}$ substituent on the aromatic ring to yield benzylhexylketone $4 \mathbf{c}(65 \%$, entry 3). The general character of this regioselective deoxygenation was confirmed with a series of other substrates 3d-n having electron-withdrawing substituents on their aromatic rings (entries 4-14). The reactions proceeded in good yields with substrates having a $p-\mathrm{CF}_{3}$ substituent (3d, 79\%, entry 4) as well as a $p-\mathrm{CO}_{2} \mathrm{Me}(3 \mathrm{e}, 68 \%$, entry 5$)$ a $p$-CN group (3f, $70 \%$, entry 6) and a $p$-COMe substituent $(\mathbf{3 g}, 70 \%$, entry 7). One can note that using substrate $\mathbf{3 h}$ having a $p$-CHO function, the deoxygenation process did not take place; only 4-(1-hydroxy-2-oxooctyl) benzaldehyde 5 was isolated in a 59\% yield after $6 \mathrm{~h}$ of stirring. ${ }^{[11]}$ Halide substituents, possibly useful for further coupling reactions, were well tolerated under these mild conditions affording the corresponding ketones 4i-n with good yields (entries 9-14). Different electron-donating groups on the aromatic ring of $\alpha$ diketones 3o-w were next evaluated (entries 15-23). As expected a OMe-substituent on the aromatic scaffold was well tolerated in this reducing process as observed in examples depicted in entries 15-18 and the corresponding alkylbenzylketones 4o-r were regioselectively isolated in good to excellent yields. In the case of $\mathbf{3 r}$, beside the total reduction of the carbonyl function close to the aromatic ring, we also observed the ether cleavage on the more fragile para$\mathrm{MeO}$-substituent of the trimethoxyphenyl ring as it was noticed, for example, with the action of Grignard reagents on trimethylpyrrogallol ether derivatives. ${ }^{[12]}$ Without surprise, $\alpha$-diketones $3 \mathbf{s}-\mathbf{x}$ bearing various electron-rich aromatic backbone $\left(4-\mathrm{OHC}_{6} \mathrm{H}_{4}\right.$, 4$\mathrm{MeC}_{6} \mathrm{H}_{4}, 4-\mathrm{SMeC}_{6} \mathrm{H}_{4}, 4-\mathrm{NHAcC}_{6} \mathrm{H}_{4}$ and 2-naphthyl) were successfully transformed into their expected benzylketones with good to excellent yields (entries 19-24). 
Table 1: Functional Group Tolerance<smiles>O=C(C(=O)c1ccccc1)C(=O)c1ccccc1</smiles>

3
1/ TMSCl / Nal ( $x$ equiv)

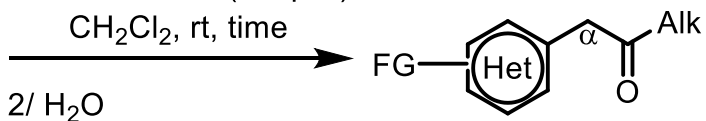

\begin{tabular}{|c|c|c|c|c|}
\hline Entry & $\alpha$-Diketone 3 & & $x^{a}$ & Tim \\
\hline 1 & & $3 a$ & 5 & 7 \\
\hline 2 & & $3 b$ & 10 & 48 \\
\hline 3 & & $3 c$ & 10 & 20 \\
\hline 4 & & $3 d$ & 10 & 20 \\
\hline 5 & & $3 e$ & 7 & 21 \\
\hline 6 & & $3 f$ & 10 & 21 \\
\hline 7 & & $3 g$ & 10 & 6 \\
\hline
\end{tabular}

8

9

10

11

12

13 $\mathrm{OHC}$<smiles>CCCCCCC(=O)C(=O)c1ccc(F)cc1</smiles><smiles>CCCCCCC(=O)C(=O)c1ccc(Cl)cc1</smiles>

3j $\quad 10 \quad 40$

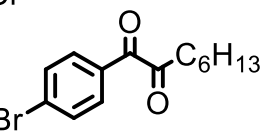

$3 \mathbf{k} 10$

31 10<smiles>O=C(Cc1ccccc1)C(=O)c1ccc(I)cc1</smiles><smiles>CCCCCCC(=O)C(=O)c1cccc(Cl)c1</smiles>

$3 m \quad 10$

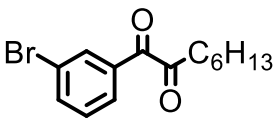

$3 n \quad 10$

24

15

16
$30 \quad 10 \quad 4$

$3 p \quad 10$ alkylbenzylketones 4

Ketones 4

Yield of 4

$(\%)^{b}$

80

90

$10 \pi_{0}^{\mathrm{C}_{6} \mathrm{H}_{13}}$

4b

$\mathrm{O}_{2} \mathrm{~N} \mathrm{O}_{\mathrm{O}}^{\mathrm{C}_{6} \mathrm{H}_{13}}$

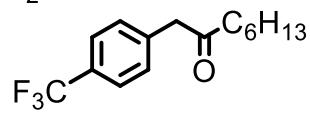

4d

79

(4)

ก

$\mathrm{OHC}_{\mathrm{O}}^{\mathrm{C}_{6} \mathrm{H}_{13}} \quad \mathbf{4 h} \quad \mathrm{O}^{d}$

$$
\text { (1i }
$$

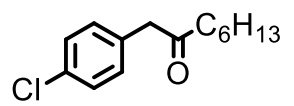

4j

97

$\overbrace{\mathrm{O}}^{\mathrm{C}_{6} \mathrm{H}_{13}}$

4k

75

$\overbrace{0}^{C_{6} \mathrm{H}_{13}}$

4I

72

$\underbrace{\mathrm{Cl}}_{0} \mathrm{C}_{6} \mathrm{H}_{13}$

$4 m$

70

${ }_{1}^{\mathrm{Br}} \pi_{\mathrm{O}}^{\mathrm{C}_{6} \mathrm{H}_{13}}$

$4 n$

65

$\mathrm{MeO}_{\mathrm{O}}^{\mathrm{C}_{6} \mathrm{H}_{13}}$

40 77

$\mathrm{MeO}_{\mathrm{O}}^{\mathrm{C}_{3} \mathrm{H}_{7}}$ 
<smiles>CCCCCCCCC(=O)C(=O)c1ccccc1OC</smiles><smiles>COc1cc(C(=O)C(=O)c2ccccc2)cc(OC)c1OC</smiles>

$3 r$

10

16

19

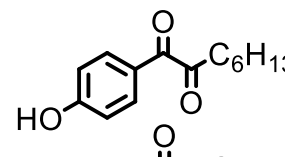

20<smiles>Cc1ccc(C(=O)C(=O)CCCO)cc1</smiles>

3s

20

48

$3 t$

10

48

21

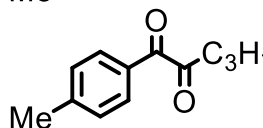

$3 u$

10

48

22

23

24
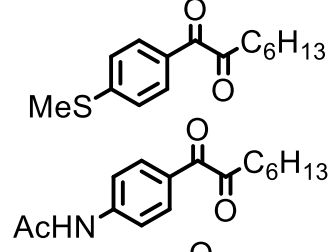

$3 v$

10

$3 w \quad 10$

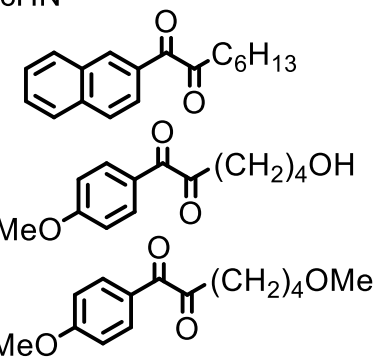

$3 x$

10

48

3y 10

$3 z \quad 10$

$3 z a$

20

$3 z b$

10

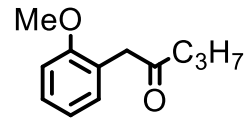

$4 q$

93

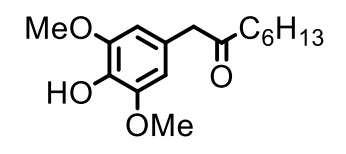

$4 r$

50

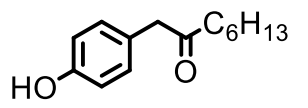

4s

$60^{c}$

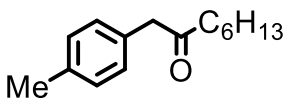

$4 t$

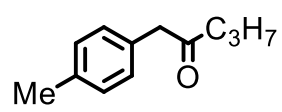

$4 u$

90

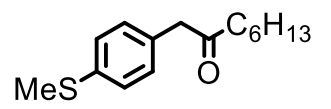

$4 v$

96

$\mathrm{AcHN}_{\mathrm{O}}^{\mathrm{C}_{6} \mathrm{H}_{13}}$

$4 w$

98

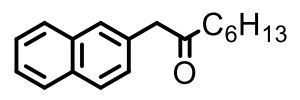

$4 x$

92

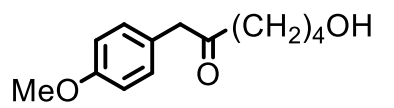

$4 y$

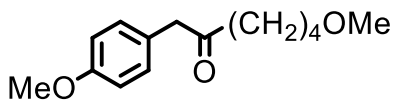

$4 z$

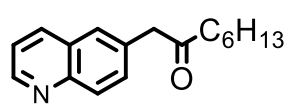

4za

65

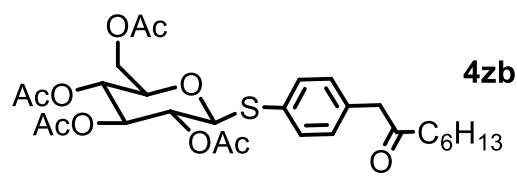

${ }^{a} x$ is the number of equivalents of the TMSCl/ $\mathrm{NaI}$ combination. ${ }^{b}$ Yield of isolated $4 .{ }^{c}$ The reaction was achieved in refluxing $\mathrm{CHCl}_{3} .{ }^{d} \mathrm{~A}$ partial reduction occurred on $\mathrm{C} \alpha$ of $\mathbf{3 h}$ to give 4-(1-hydroxy-2-oxooctyl)benzaldehyde $\mathbf{5}$ in a yield of $59 \%$, see ref. ${ }^{[11]}$

To our delight, variations on the alkyl chain of compounds $\mathbf{3}$ were also allowed and primary alcohol $\mathbf{3 y}$ and its methyl ether $\mathbf{3 z}$ were converted into their corresponding reduced products $\mathbf{4 y}$ and $\mathbf{4 z}$ in $80 \%$ and $78 \%$ yields, respectively (entries 25 and 26). Next, we focused our attention on $\alpha$-diketone 3za bearing an alkyl chain and a quinoline-scaffold and showed that the replacement of a phenyl ring by a 6-quinolyl substituent was also possible as ketone 4za was obtained in an acceptable $65 \%$ yield (entry 27 ). Lastly, the sugar derivative 3zb, prepared from the $\mathrm{Pd}$ coupling reaction between $\beta$-thioglucose and $\mathbf{3 1},{ }^{[13]}$ was subjected to the reducing $\mathrm{TMSCl} / \mathrm{NaI}$ process. We were pleased to observe that the regioselective reduction of the $\mathrm{C} \alpha=\mathrm{O}$ of $\mathbf{3 z b}$ occurred smoothly to provide 4zb $(52 \%$ yield $)$ without anomeric epimerization (entry 28).
The results reported in Table 1 clearly demonstrate that the $\mathrm{TMSCl} / \mathrm{NaI}$ protocol could be applied on a large variety of alkylaryl- $\alpha$-diketones $\mathbf{3}$ bearing on their aromatic rings various substituents whatever their electronic character on the ortho-, meta-, and parapositions. Then, to evaluate whether the presence of an aryl substituent was essential in the deoxygenation of arylalkyl-1,2-diketones $\mathbf{3}$, we have also studied the reaction with octan-1,2-dione as a model of dialkyl1,2-diketone. After 30 minutes of stirring at $\mathrm{rt}$ in the presence of 10 equiv of TMSCl/NaI, octan-1,2-dione was rapidly totally degraded to give a mixture of unidentified by-products. Achieving the reaction at lower temperatures $\left(0{ }^{\circ} \mathrm{C}\right.$ and $\left.-20^{\circ} \mathrm{C}\right)$ with reduced reaction times (10 and 20 minutes) did not give better results. Next, we were interested to evaluate the TMSCl/NaI association as a potent reducing reagent using other 
actived groups, such as for example $\alpha$-ketoesters 6ad, $\alpha$-ketoacids $\mathbf{7 a , b}$ and $\alpha$-hydrazidoester $\mathbf{8}$ (Table 2).

Table 2. Deoxygenation of 6-8 by the TMSCl/NaI combination

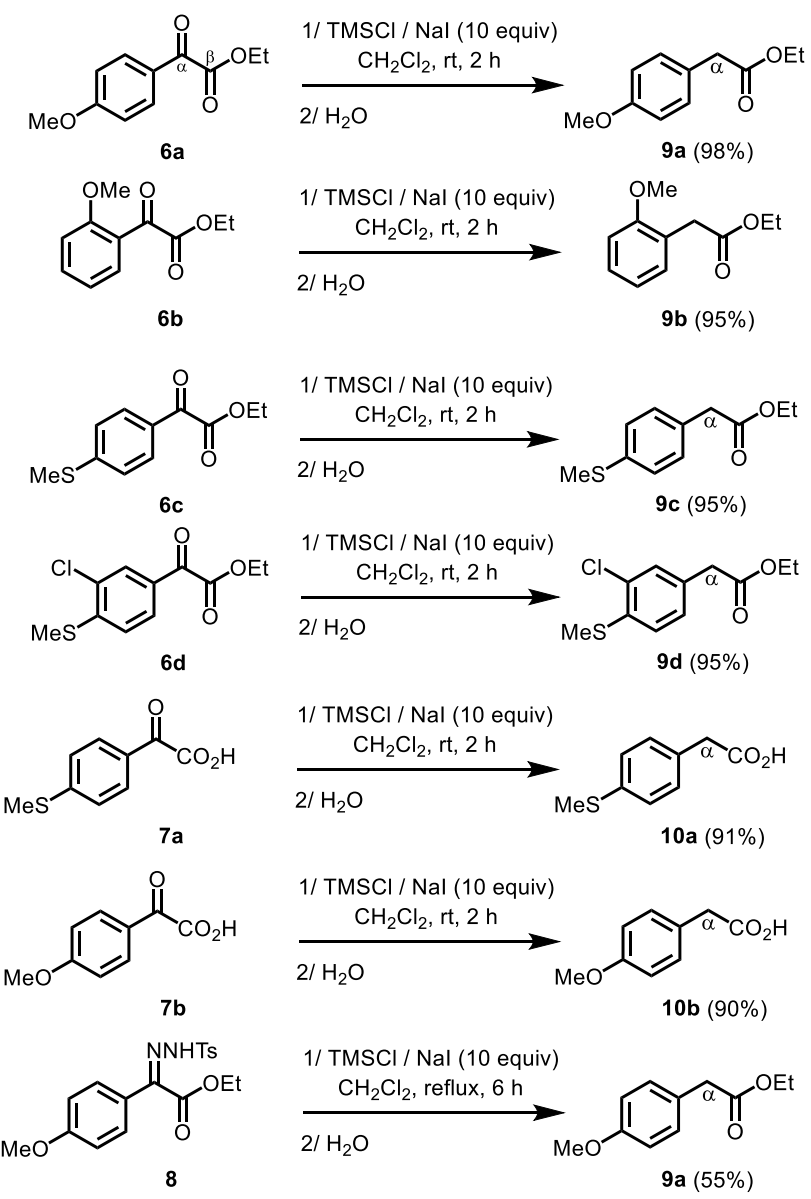

Under the standard conditions defined in Table 1, the total reduction the keto-group of $\mathbf{6 a}$ and $\mathbf{6 b}$ proceeded smoothly to give the corresponding benzylesters $9 \mathbf{a}$ and $9 \mathrm{~b}$ in a nearly quantitative yield after $2 \mathrm{~h}$ of reaction with a total $\alpha$-selectivity. The TMSCl/NaI process was next used in view of reducing the carbonyl function of $\alpha$-ketoesters $\mathbf{6 c}$ and $\mathbf{6 d}$. After $2 \mathrm{~h}$ of reaction, the desired benzylesters $9 \mathbf{c}$ and $9 d$ were obtained again with excellent yields (95\%). For comparisons, the deoxygenation of $\mathbf{6 d}$ into $9 \mathbf{d}$ was recently reported, ${ }^{[14]}$ but required a three-step sequence in a $20 \%$ overall yield $[(i)$ reduction of the ketogroup of 6d into alcohol using $\mathrm{NaBH}_{4}$ (ii) acetylation of the alcohol function, and (iii) reduction of the resulting acetate by $\left.\mathrm{SmI}_{2}\right]$. As observed with $\alpha$ ketoester 6, we were pleased to observe the carbonyl deoxygenation $\alpha$-ketoacids $\mathbf{7 a}, \mathbf{b}$ by the $\mathrm{TMSCl} / \mathrm{NaI}$ association to provide 2-phenylacetic acids 10a,b in similar good yields of $91 \%$ and $90 \%$, respectively. A last trial was successfully attempted with arylalkyl1,2-hydrazido-ester 8 which was chemoselectively reduced after $6 \mathrm{~h}$ of reaction by the TMSCl/NaI combination in refluxing $\mathrm{CH}_{2} \mathrm{Cl}_{2}$ to provide benzylester 9a in an acceptable 55\% yield. The comparison of the results obtained with derivatives $\mathbf{6 a}$ and $\mathbf{8}$ indicated that the deoxygenation by TMSCl/NaI of the keto-group of $\mathbf{6 a}$ seems to be easier than the deoxygenation of the hydrazide-function of $\mathbf{8}$ to provide the same benzylester derivative 9a $(98 \%, 2 \mathrm{~h}$ for $6 \mathbf{a} v s 55 \%, 6 \mathrm{~h}$ reflux for $\mathbf{8}$ ). All of the results presented in Table 2 indicated that $\mathrm{TMSCl} / \mathrm{NaI}$ is a combination of choice for the mild deoxygenation of $\alpha$-ketoesters and also for other functionalities, such as $\alpha$-ketoacids or $\alpha$-hydrazidoesters.

\section{Conclusion}

In summary, we demonstrated, for the first time, that TMSCl associated to $\mathrm{NaI}$ in $\mathrm{CH}_{2} \mathrm{Cl}_{2}$ is a useful combination to regioselectively reduce a variety of arylalkyl- $\alpha$-diketones 3 . The keto group of these $\alpha$ diketones, which is proximal to the aryl ring, was totally reduced into methylene to provide the corresponding alkylbenzylketones $\mathbf{4}$ in good to excellent yields. The present method can be used for the deoxygenation of a large variety of arylalkyl- $\alpha$ diketones 3 bearing a wide range of functional groups on the aromatic ring with extreme ease at rt. On the contrary to the deoxygenation of benzil derivatives, which require the presence of an electron-donating substituent on the ortho- or para-positions of the aromatic ring, the deoxygenation of substituted arylalkyl-1,2-diketones $\mathbf{3}$ efficiently takes place regardless the electronic nature of the substituent (electron-withdrawing or electron-donating). Moreover, heterocyclic systems as a quinoline and sugar derivatives are also allowed making this elegant reducible method applicable to many compounds of type 3. This mild process was successfully applied to $\alpha$-ketoesters, $\alpha$-ketoacids and $\alpha$-hydrazidoesters, which were cleanly reduced with high yields. We believe that this soft and easy to handle methodology should find broad applications in synthetic organic chemistry, as well as in the combinatorial and pharmaceutical sciences.

\section{Experimental Section}

\section{General experimental methods}

All reactions were conducted under an argon atmosphere. Solvents: methylene chloride $\left(\mathrm{CH}_{2} \mathrm{Cl}_{2}\right)$ for reaction, cyclohexane, ethyl acetate (EtOAc) for extraction and chromatography were technical grade. These compounds were all identified by the usual physical methods that are ${ }^{1} \mathrm{H}$ NMR, ${ }^{13} \mathrm{C}$ NMR, IR, HR-MS (ESI or APCI). ${ }^{1} \mathrm{H}$ NMR, ${ }^{13} \mathrm{C}$ NMR spectra were measured in $\mathrm{CDCl}_{3}$ with an Advance 300. ${ }^{1} \mathrm{H}$ chemical shift are reported in ppm from an internal standard TMS or of residual chloroform (7.26 ppm). The following abreviations are used: $\mathrm{m}$ (multiplet), $\mathrm{s}$ (singlet), $\mathrm{d}$ (doublet), $\mathrm{t}$ (triplet), dd (doublet of doublet), q (quartet). ${ }^{13} \mathrm{C}$ 
chemical shift are reported in ppm from central peak of deuteriochloroform (77.14). High-resolution mass spectra (HR-MS) were recorded on a MicroTOF spectrometer, using ESI or APCI with methanol as the carrier solvent. FTIR spectra were measured on a Vector 22 spectrometer and are reported in wave numbers $\left(\mathrm{cm}^{-1}\right)$. Analytical TLC was performed on precoated silica gel 60-F254 plates. Silica gel 60 was used for flash chromatography. Melting points were recorded on a B-450 apparatus and are uncorrected. Arylalkyl- $\alpha$-diketones $\mathbf{3}$ were prepared according to literature. ${ }^{[9]}$ Ketones $\mathbf{4 a},{ }^{[15]} \mathbf{4 b},{ }^{[16]} \mathbf{4} \mathbf{p}^{[17]}$ and $\mathbf{4 t ^ { [ 1 8 ] }}$ are known products and their spectroscopic data are in agreement with literature. 9a, ${ }^{[19]} \mathbf{9 b},{ }^{[20]} \mathbf{9 c},{ }^{[21]} \mathbf{1 0 b} \mathbf{b}^{[22]}$ are known products and their spectroscopic data are in agreement with literature.

\section{General procedure for deoxygenation of arylalkyl- $\alpha$ - diketones 3}

Typical example: under argon, $109 \mathrm{mg}(0.5 \mathrm{mmol})$ of diketone $\mathbf{3 b}$ and $750 \mathrm{mg}(5 \mathrm{mmol})$ of $\mathrm{NaI}$ were mixed in 10 $\mathrm{mL}$ of $\mathrm{CH}_{2} \mathrm{Cl}_{2}$. The resulting mixture was stirred for $5 \mathrm{~min}$. at $\mathrm{rt}$ and then $540 \mathrm{mg}(5 \mathrm{mmol})$ of TMSCl were added to the solution. After disappearance of $\mathbf{3 b}$ (judged by TLC; $48 \mathrm{~h}$ ), the dark mixture was washed with $10 \mathrm{~mL}$ of a saturated $\mathrm{Na}_{2} \mathrm{~S}_{2} \mathrm{O}_{3}$ solution and extracted with $\mathrm{CH}_{2} \mathrm{Cl}_{2}$. After drying on $\mathrm{Na}_{2} \mathrm{SO}_{4}$ and concentration, the crude was purified by silica gel column chromatography to give benzylhexylketone $\mathbf{4 b}$ (92 $\mathrm{mg}, 90 \%)$.

1-Phenylpropan-2-one (4a) ${ }^{[15]}$

Compound 4a was prepared according to the general procedure using 1-phenylpropane-1,2-dione 3a (100 mg, $0.6749 \mathrm{mmol})$. The title compound was obtained after flash chromatography as yellow liquid; yield 80\% (72.4 $\mathrm{mg}),{ }_{1}^{1} \mathrm{H}$ NMR $\left(300 \mathrm{MHz}, \mathrm{CDCl}_{3}\right) \delta$ 7.65-7.01 (m, 5H), $3.63(\mathrm{~s}, 2 \mathrm{H}), 2.08(\mathrm{~s}, 3 \mathrm{H}) ;{ }^{13} \mathrm{C} \mathrm{NMR}\left(75 \mathrm{MHz} \mathrm{CDCl}_{3}\right) \delta$ 206.40, 134.24, 129.38, 128.76, 127.07, 51.05, 29.27.

\section{1-Phenyloctan-2-one (4b)}

Compound 4b was prepared according to the general procedure using 1-phenyloctane-1,2-dione $\mathbf{3 b}(100 \mathrm{mg}$, $0.4581 \mathrm{mmol})$. The title compound was obtained after flash chromatography as yellow liquid; yield 90\% (84.2 $\mathrm{mg}) ;{ }^{1} \mathrm{H} \mathrm{NMR}\left(300 \mathrm{MHz}, \mathrm{CDCl}_{3}\right) \delta 7.40-7.12(\mathrm{~m}, 5 \mathrm{H})$, $3.69(\mathrm{~s}, 2 \mathrm{H}), 2.45(\mathrm{t}, J=7.4 \mathrm{~Hz}, 2 \mathrm{H}), 1.70-1.50(\mathrm{~m}, 2 \mathrm{H})$, $1.35-1.20(\mathrm{~m}, 6 \mathrm{H}), 0.87(\mathrm{t}, J=6.7 \mathrm{~Hz}, 3 \mathrm{H}) ;{ }^{13} \mathrm{C}$ NMR $(75$ $\left.\mathrm{MHz} \mathrm{CDCl}_{3}\right) \delta 208.56,134.41,129.38,128.67,126.92$, 50.15, 42.00, 31.54, 28.77, 23.71, 22.46, 13.99 .

\section{1-(4-Nitrophenyl)octan-2-one (4c)}

Compound $\mathbf{4 c}$ was prepared according to the general procedure using 1-(4-nitrophenyl)octan-1,2-dione 3c (100 $\mathrm{mg}, 0.38 \mathrm{mmol})$. The title compound was obtained after flash chromatography as orange liquid; yield $65 \%(61.5$ $\mathrm{mg}) ;{ }^{1} \mathrm{H}$ NMR $\left(300 \mathrm{MHz}, \mathrm{CDCl}_{3}\right) \delta 8.18(\mathrm{~d}, J=8.2 \mathrm{~Hz}$, $2 \mathrm{H}), 7.35(\mathrm{~d}, J=8.4 \mathrm{~Hz}, 2 \mathrm{H}), 3.81(\mathrm{~s}, 2 \mathrm{H}), 2.50(\mathrm{t}, J=7.4$ $\mathrm{Hz}, 2 \mathrm{H}), 1.60-1.50$ (m, 2H), 1.29-1.20 (m, 6H), $0.86(\mathrm{t}, J$ $=6.4 \mathrm{~Hz}, 3 \mathrm{H}) ;{ }^{13} \mathrm{C} \mathrm{NMR}\left(75 \mathrm{MHz}, \mathrm{CDCl}_{3}\right) \delta 206.52$, 147.05, 141.67, 130.43, 123.73, 49.21, 42.83, 31.51, $28.75,23.65,22.44,13.98$; FT-IR (neat, $\mathrm{cm}^{-1}$ ): 1714, 1603, 1516, 1494, 1467, 1406, 1344, 1182, 1109, 1064, 1016; HRMS (ESI positive, $\mathrm{m} / \mathrm{z}$ ): found 272.1268 $\left([\mathrm{M}+\mathrm{Na}]^{+}\right)$, calc. for $\mathrm{C}_{14} \mathrm{H}_{19} \mathrm{NNaO}_{3}(\mathrm{M}+\mathrm{Na}): 272.1263$. Flash chromatography conditions: Cyclohexane/EtOAc 100/0 to 90/10; $\mathrm{R}_{\mathrm{f}}=0.46$ (Cyclohexane/EtOAc: $\left.9 / 1\right)$.

1-(4-(Trifluoromethyl)phenyl)octan-2-one (4d)
Compound 4d was prepared according to the general procedure using 1-(4-nitrophenyl)octane-1,2-dione 3d (100 mg, $0.35 \mathrm{mmol}$ ). The title compound was obtained after flash chromatography as brown liquid; yield $79 \%$ $(75.1 \mathrm{mg}) ;{ }^{1} \mathrm{H}$ NMR $\left(300 \mathrm{MHz}, \mathrm{CDCl}_{3}\right) \delta 7.58(\mathrm{~d}, J=8.1$ $\mathrm{Hz}, 2 \mathrm{H}), 7.31(\mathrm{~d}, J=8.0 \mathrm{~Hz}, 2 \mathrm{H}), 3.75(\mathrm{~s}, 2 \mathrm{H}), 2.47(\mathrm{t}, J$ $=7.4 \mathrm{~Hz}, 2 \mathrm{H}), 1.61-1.54(\mathrm{~m}, 2 \mathrm{H}), 1.30-1.20(\mathrm{~m}, 6 \mathrm{H}), 0.86$ $(\mathrm{t}, J=6.6 \mathrm{~Hz}, 3 \mathrm{H}) ;{ }^{13} \mathrm{C} \mathrm{NMR}\left(75 \mathrm{MHz}, \mathrm{CDCl}_{3}\right) \delta 207.38$, 138.25, 129.81, 125.51, 49.50, 42.50, 31.53, 28.76, 23.67, $22.46,14.00 ;{ }^{19} \mathrm{~F}$ NMR $\left(188 \mathrm{MHz}, \mathrm{CDCl}_{3}\right) \delta-62.94$; FTIR (neat, $\mathrm{cm}^{-1}$ ): 1716, 1419, 1368, 1325, 1164, 1126, 1111, 1067, 1020; HRMS (ESI positive, $\mathrm{m} / \mathrm{z}$ ): found 295.1287 $\left([\mathrm{M}+\mathrm{Na}]^{+}\right)$, calc. for $\mathrm{C}_{15} \mathrm{H}_{19} \mathrm{~F}_{3} \mathrm{NaO}(\mathrm{M}+\mathrm{Na})$ : 295.1286 . Flash chromatography conditions: Cyclohexane/EtOAc 100/0 to 90/10; $\mathrm{R}_{\mathrm{f}}=0.52$ (Cyclohexane/EtOAc: $9 / 1$ ).

\section{Methyl 4-(2-oxooctyl)benzoate (4e)}

Compound $4 \mathbf{e}$ was prepared according to the general procedure using methyl 4-(2-oxooctanoyl)benzoate $\mathbf{3 e}$ (100 mg, $0.36 \mathrm{mmol}$ ). The title compound was obtained after flash chromatography as yellow liquid; yield $68 \%$ (64.5 mg); ${ }^{1} \mathrm{H}$ NMR (300 MHz, $\left.\mathrm{CDCl}_{3}\right) \delta 7.93(\mathrm{~d}, J=8.2$ $\mathrm{Hz}, 2 \mathrm{H}), 7.20(\mathrm{~d}, J=8.0 \mathrm{~Hz}, 2 \mathrm{H}), 3.84(\mathrm{~s}, 3 \mathrm{H}), 3.67$ (s, $2 \mathrm{H}), 2.38(\mathrm{t}, J=7.4 \mathrm{~Hz}, 2 \mathrm{H}), 1.56-1.46(\mathrm{~m}, 2 \mathrm{H}), 1.29-1.12$ $(\mathrm{m}, 6 \mathrm{H}), 0.79(\mathrm{t}, J=6.7 \mathrm{~Hz}, 3 \mathrm{H}) ;{ }^{13} \mathrm{C} \mathrm{NMR}(75 \mathrm{MHz}$, $\left.\mathrm{CDCl}_{3}\right) \delta 207.52,166.85,139.52,129.91,129.49,128.87$, 52.08, 49.86, 42.38, 31.52, 28.74, 23.65, 22.44, 13.99; FTIR (neat, $\mathrm{cm}^{-1}$ ): 1725, 1712, 1612, 1436, 1280, 1107, 1021, 969, 906; HRMS (ESI positive, $\mathrm{m} / \mathrm{z}$ ): found 285.1467 $\left([\mathrm{M}+\mathrm{Na}]^{+}\right)$, calc. for $\mathrm{C}_{16} \mathrm{H}_{22} \mathrm{NaO}_{3}(\mathrm{M}+\mathrm{Na})$ : 285.1467; Flash chromatography conditions: Cyclohexane/EtOAc 100/0 to 80/20; $\mathrm{R}_{\mathrm{f}}=0.40$ (Cyclohexane/EtOAc: $7 / 3$ ).

\section{4-(2-Oxooctyl)benzonitrile (4f)}

Compound $\mathbf{4 f}$ was prepared according to the general procedure using 4-(2-oxooctanoyl)benzonitrile 3f (100 $\mathrm{mg}, 0.41 \mathrm{mmol})$. The title compound was obtained after flash chromatography as colorless liquid; yield 70\% (66.0 $\mathrm{mg}) ;{ }^{1} \mathrm{H} \mathrm{NMR}\left(300 \mathrm{MHz}, \mathrm{CDCl}_{3}\right) \delta 7.62(\mathrm{~d}, J=7.6 \mathrm{~Hz}$, $2 \mathrm{H}), 7.30(\mathrm{~d}, J=7.7 \mathrm{~Hz}, 2 \mathrm{H}), 3.76(\mathrm{~s}, 2 \mathrm{H}), 2.48$ (t, $J=7.3$ $\mathrm{Hz}, 2 \mathrm{H}), 1.59-1.55$ (m, 2H), 1.25-1.15 (m, 6H), 0.86 (t, $J$ $=6.4 \mathrm{~Hz}, 3 \mathrm{H}) ;{ }^{13} \mathrm{C} \mathrm{NMR}\left(75 \mathrm{MHz}, \mathrm{CDCl}_{3}\right) \delta 206.76$, 139.61, 132.33, 130.32, 118.74, 110.96, 49.55, 42.75, $31.52,28.75,23.65,22.45,14.01$; FT-IR (neat, $\mathrm{cm}^{-1}$ ): 2229, 1716, 1609, 1505, 1468, 1416, 1377, 1306, 1273, 1178, 1127, 1100, 1065, 1021; HRMS (ESI positive, m/z): found $230.1542\left([\mathrm{M}+\mathrm{H}]^{+}\right)$, calc. for $\mathrm{C}_{15} \mathrm{H}_{19} \mathrm{NO}(\mathrm{M}+\mathrm{H})$ : 230.1545; Flash chromatography conditions: Cyclohexane/EtOAc $100 / 0$ to $80 / 20 ; \quad \mathrm{R}_{\mathrm{f}}=0.35$ (Cyclohexane/EtOAc: 7/3).

\section{1-(4-Acetylphenyl)octan-2-one (4g)}

Compound $\mathbf{4 g}$ was prepared according to the general procedure using 1-(4-acetylphenyl)octane-1,2-dione $\mathbf{3 g}$ (100 mg, $0.38 \mathrm{mmol}$ ). The title compound was obtained after flash chromatography as colorless liquid; yield $70 \%$ $(66.2 \mathrm{mg}) ;{ }^{1} \mathrm{H}$ NMR $\left(300 \mathrm{MHz}, \mathrm{CDCl}_{3}\right) \delta 7.93(\mathrm{~d}, J=8.1$ $\mathrm{Hz}, 2 \mathrm{H}), 7.30(\mathrm{~d}, J=8.1 \mathrm{~Hz}, 2 \mathrm{H}), 3.75(\mathrm{~s}, 2 \mathrm{H}), 2.60(\mathrm{~s}$, $3 \mathrm{H}), 2.47(\mathrm{t}, J=7.4 \mathrm{~Hz}, 2 \mathrm{H}), 1.45-1.10(\mathrm{~m}, 8 \mathrm{H}), 0.86(\mathrm{t}, J$ $=6.6 \mathrm{~Hz}, 3 \mathrm{H}) ;{ }^{13} \mathrm{C} \mathrm{NMR}\left(75 \mathrm{MHz}, \mathrm{CDCl}_{3}\right) \delta 207.45$, $197.69,139.73,135.89,129.70,128.70,49.80,42.48$, 31.52, 28.76, 26.61, 23.67, 22.45, 14.00; FT-IR (neat, $\mathrm{cm}^{-}$ $\left.{ }^{1}\right)$ : 2958, 2930, 2856, 1760, 1716, 1683, 1607, 1361, 1268, 1228, 1215, 1184, 1080, 1036, 956, 904; HRMS (ESI positive, $m / z)$ : found $269.1521\left([\mathrm{M}+\mathrm{Na}]^{+}\right)$, calc. for 
$\mathrm{C}_{16} \mathrm{H}_{22} \mathrm{NaO}_{2}(\mathrm{M}+\mathrm{Na}): 269.1517$. Flash chromatography conditions: Cyclohexane/EtOAc 100/0 to 90/10; $\mathrm{R}_{\mathrm{f}}=0.45$ (Cyclohexane/EtOAc: 9/1).

\section{1-(4-Fluorophenyl)octan-2-one (4i)}

Compound 4i was prepared according to the general procedure using 1-(4-fluorophenyl)octane-1,2-dione $\mathbf{3 i}$ (100 mg, $0.42 \mathrm{mmol}$ ). The title compound was obtained after flash chromatography as colorless liquid; yield $85 \%$ $(80.0 \mathrm{mg}) ;{ }^{1} \mathrm{H}$ NMR $\left(400 \mathrm{MHz}, \mathrm{CDCl}_{3}\right) \delta$ 7.17-7.14 (m, 2H), 7.03-6.99 (m, 2H), $3.65(\mathrm{~s}, 2 \mathrm{H}), 2.44(\mathrm{t}, J=7.4 \mathrm{~Hz}$, $2 \mathrm{H}), 1.57-1.53(\mathrm{~m}, 2 \mathrm{H}), 1.30-1.24(\mathrm{~m}, 6 \mathrm{H}), 0.86(\mathrm{t}, J=6.8$ $\mathrm{Hz}, 3 \mathrm{H}) ;{ }^{13} \mathrm{C}$ NMR $\left(101 \mathrm{MHz}, \mathrm{CDCl}_{3}\right) \delta 208.39,162.07$ $(\mathrm{d}, J=245.4 \mathrm{~Hz}), 131.03(\mathrm{~d}, J=7.9 \mathrm{~Hz}), 130.19,115.63$ $(\mathrm{d}, J=21.4 \mathrm{~Hz}), 49.17,42.25,31.66,28.91,23.84,22.58$, 14.11; ${ }^{19} \mathrm{~F}$ NMR $\left(188 \mathrm{MHz}, \mathrm{CDCl}_{3}\right) \delta-115.97$; FT-IR $\left(\right.$ neat, $\left.\mathrm{cm}^{-1}\right): 1714,1602,1581,1510,1466,1414,1333$, 1223, 1180, 1158, 1129, 1035, 1008; HRMS (ESI positive, $m / z)$ : found $223.1498\left([\mathrm{M}+\mathrm{H}]^{+}\right)$, calc. for $\mathrm{C}_{14} \mathrm{H}_{20} \mathrm{FO}$ $(\mathrm{M}+\mathrm{H})$ : 223.1498; Flash chromatography conditions: Cyclohexane/EtOAc $100 / 0$ to $90 / 10 ; \quad \mathrm{R}_{\mathrm{f}}=0.65$ (Cyclohexane/EtOAc: 95/5).

\section{1-(4-Chlorophenyl)octan-2-one $(4 \mathbf{j})$}

Compound $\mathbf{4} \mathbf{j}$ was prepared according to the general procedure using 1-(4-chlorophenyl)octane-1,2-dione $\mathbf{3 j}$ (100 mg, $0.40 \mathrm{mmol}$ ). The title compound was obtained after flash chromatography as yellow liquid; yield $97 \%$ (91.6 mg); ${ }^{1} \mathrm{H}$ NMR (300 MHz, $\left.\mathrm{CDCl}_{3}\right) \delta 7.29(\mathrm{~d}, J=8.3$ $\mathrm{Hz}, 2 \mathrm{H}), 7.12(\mathrm{~d}, J=8.3 \mathrm{~Hz}, 2 \mathrm{H}), 3.65(\mathrm{~s}, 2 \mathrm{H}), 2.44(\mathrm{t}, J$ $=7.4 \mathrm{~Hz}, 2 \mathrm{H}), 1.57-1.50(\mathrm{~m}, 2 \mathrm{H}), 1.30-1.23(\mathrm{~m}, 6 \mathrm{H}), 0.86$ $(\mathrm{t}, J=6.5 \mathrm{~Hz}, 3 \mathrm{H}) ;{ }^{13} \mathrm{C} \mathrm{NMR}\left(75 \mathrm{MHz}, \mathrm{CDCl}_{3}\right) \delta 208.01$, 132.74, 130.76, 128.78, 49.18, 42.22, 31.54, 28.77, 23.68, 22.47, 14.01; FT-IR (neat, $\mathrm{cm}^{-1}$ ): 1758, 1713, 1610, 1512, 1492, 1467, 1407, 1378, 1269, 1214, 1167, 1128, 1091, 1065, 1016, 908; HRMS (ESI positive, $\mathrm{m} / \mathrm{z}$ ): found $239.1197\left([\mathrm{M}+\mathrm{H}]^{+}\right)$, calc. for $\mathrm{C}_{14} \mathrm{H}_{20} \mathrm{ClO}(\mathrm{M}+\mathrm{H})$ : 239.1203; Flash chromatography conditions: Cyclohexane/EtOAc $100 / 0 \quad$ to $90 / 10 ; \quad \mathrm{R}_{\mathrm{f}}=0.60$ (Cyclohexane/EtOAc: 95/5).

\section{1-(4-Bromophenyl)octan-2-one (4k)}

Compound 4k was prepared according to the general procedure using 1-(4-bromophenyl)octane-1,2-dione $\mathbf{3 i}$ (100 mg, $0.336 \mathrm{mmol}$ ). The title compound was obtained after flash chromatography as brown liquid; yield $75 \%$ $(71.5 \mathrm{mg}) ;{ }^{1} \mathrm{H}$ NMR $\left(300 \mathrm{MHz}, \mathrm{CDCl}_{3}\right) \delta 7.45(\mathrm{~d}, J=8.3$ $\mathrm{Hz}, 2 \mathrm{H}), 7.07$ (d, $J=8.2 \mathrm{~Hz}, 2 \mathrm{H}), 3.63$ (s, 2H), 2.44 (t, $J$ $=7.4 \mathrm{~Hz}, 2 \mathrm{H}), 1.60-1.43(\mathrm{~m}, 2 \mathrm{H}), 1.26-1.10(\mathrm{~m}, 6 \mathrm{H}), 0.86$ $(\mathrm{t}, J=6.6 \mathrm{~Hz}, 3 \mathrm{H}) ;{ }^{13} \mathrm{C} \mathrm{NMR}\left(75 \mathrm{MHz}, \mathrm{CDCl}_{3}\right) \delta 207.96$, $133.24,131.75,131.15,121.00,49.26,42.25,31.55$, 28.78, 23.68, 22.48, 14.04; FT-IR (neat, $\mathrm{cm}^{-1}$ ): 1713, 1589, 1488, 1466, 1405, 1187, 1128, 1071, 1012, 909; HRMS (ESI positive, $\mathrm{m} / \mathrm{z}$ ): found $305.0516\left([\mathrm{M}+\mathrm{Na}]^{+}\right)$, calc. for $\mathrm{C}_{14} \mathrm{H}_{19} \mathrm{BrNaO}(\mathrm{M}+\mathrm{Na})$ : 305.0517; Flash chromatography conditions: Cyclohexane/EtOAc 100/0 to 90/10; $\mathrm{R}_{\mathrm{f}}=0.55$ (Cyclohexane/EtOAc: $\left.95 / 5\right)$.

\section{1-(4-Iodophenyl)octan-2-one (4l)}

Compound 41 was prepared according to the general procedure using 1-(4-iodophenyl)octane-1,2-dione 3l (100 $\mathrm{mg}, 0.29 \mathrm{mmol})$. The title compound was obtained after flash chromatography as brown liquid; yield $72 \%$ (69.1 $\mathrm{mg}) ;{ }^{1} \mathrm{H}$ NMR (300 MHz, $\left.\mathrm{CDCl}_{3}\right) \delta 7.65(\mathrm{~d}, J=8.3 \mathrm{~Hz}$, $2 \mathrm{H}), 6.94(\mathrm{~d}, J=8.2 \mathrm{~Hz}, 2 \mathrm{H}), 3.62(\mathrm{~s}, 2 \mathrm{H}), 2.43(\mathrm{t}, J=7.4$ $\mathrm{Hz}, 2 \mathrm{H}), 1.55-1.50$ (m, 2H), 1.28-1.23 (m, 6H), 0.86 (t, $J$
$=6.6 \mathrm{~Hz}, 3 \mathrm{H}) ;{ }^{13} \mathrm{C} \mathrm{NMR}\left(101 \mathrm{MHz}, \mathrm{CDCl}_{3}\right) \delta 207.82$, $137.84,134.07,131.53,92.52,49.48,42.37,31.65,28.89$, 23.82, 22.57, 14.11; FT-IR (neat, $\mathrm{cm}^{-1}$ ): 1713, 1581, 1485, 1465, 1401, 1377, 1261, 1185, 1126, 1103, 1060, 1007; HRMS (ESI positive, $\mathrm{m} / \mathrm{z}$ ): found $331.0556\left([\mathrm{M}+\mathrm{H}]^{+}\right)$, calc. for $\mathrm{C}_{14} \mathrm{H}_{20} \mathrm{IO}(\mathrm{M}+\mathrm{H})$ : 331.0559; Flash chromatography conditions: Cyclohexane/EtOAc 100/0 to 90/10; $R_{\mathrm{f}}=0.50$ (Cyclohexane/EtOAc: $\left.95 / 5\right)$.

\section{1-(3-Chlorophenyl)octan-2-one (4m)}

Compound $\mathbf{4 m}$ was prepared according to the general procedure using 1-(3-chlorophenyl)octane-1,2-dione 3m (100 mg, $0.396 \mathrm{mmol}$ ). The title compound was obtained after flash chromatography as yellow liquid; yield $70 \%$ $(66.1 \mathrm{mg}) ;{ }^{1} \mathrm{H}$ NMR $\left(300 \mathrm{MHz}, \mathrm{CDCl}_{3}\right) \delta 7.21-7.15(\mathrm{~m}$, $2 \mathrm{H}), 7.13(\mathrm{~s}, 1 \mathrm{H}), 7.05-6.95(\mathrm{~m}, 1 \mathrm{H}), 3.58(\mathrm{~s}, 2 \mathrm{H}), 2.38$ $(\mathrm{t}, J=7.4 \mathrm{~Hz}, 2 \mathrm{H}), 1.51-1.44(\mathrm{~m}, 2 \mathrm{H}), 1.26-1.17(\mathrm{~m}, 6 \mathrm{H})$, $0.79(\mathrm{t}, J=6.6 \mathrm{~Hz}, 3 \mathrm{H}) ;{ }^{13} \mathrm{C} \mathrm{NMR}\left(75 \mathrm{MHz}, \mathrm{CDCl}_{3}\right) \delta$ $207.62,136.20,134.42,129.83,129.55,127.61,127.16$, 49.41, 42.29, 31.53, 28.76, 23.67, 22.45, 13.99; FT-IR (neat, $\mathrm{cm}^{-1}$ ): 1714, 1598, 1574, 1515, 1476, 1433, 1365, 1271, 1208, 1126, 1080; HRMS (ESI positive, $m / z$ ): found $261.1022\left([\mathrm{M}+\mathrm{Na}]^{+}\right)$, calc. for $\mathrm{C}_{14} \mathrm{H}_{19} \mathrm{ClNaO}(\mathrm{M}+\mathrm{Na})$ : 261.1030; Flash chromatography conditions: Cyclohexane/EtOAc $100 / 0$ to $90 / 10 ; \quad R_{\mathrm{f}}=0.65$ (Cyclohexane/EtOAc: 95/5).

\section{1-(3-Bromophenyl)octan-2-one (4n)}

Compound $4 \mathbf{n}$ was prepared according to the general procedure using 1-(3-bromophenyl)octane-1,2-dione 3n $(100 \mathrm{mg}, 0.336 \mathrm{mmol})$. The title compound was obtained after flash chromatography as brown liquid; yield $65 \%$ $(61.9 \mathrm{mg}) ;{ }^{1} \mathrm{H}$ NMR $\left(300 \mathrm{MHz}, \mathrm{CDCl}_{3}\right) \delta 7.51-7.31(\mathrm{~m}$, 2H), $7.19(\mathrm{t}, J=7.7 \mathrm{~Hz}, 1 \mathrm{H}), 7.12(\mathrm{~d}, J=7.7 \mathrm{~Hz}, 1 \mathrm{H}), 3.65$ $(\mathrm{s}, 2 \mathrm{H}), 2.45(\mathrm{t}, J=7.4 \mathrm{~Hz}, 2 \mathrm{H}), 1.58-1.53(\mathrm{~m}, 2 \mathrm{H}), 1.29$ $1.24(\mathrm{~m}, 6 \mathrm{H}), 0.86(\mathrm{t}, J=6.6 \mathrm{~Hz}, 3 \mathrm{H}) .{ }^{13} \mathrm{C} \mathrm{NMR}(75 \mathrm{MHz}$, $\left.\mathrm{CDCl}_{3}\right) \delta 207.57,136.49,132.44,130.09,128.07,122.63$, 49.35, 42.30, 31.53, 28.76, 23.67, 22.45, 13.99; FT-IR (neat, $\mathrm{cm}^{-1}$ ): 1714, 1596, 1569, 1473, 1429, 1406, 1376, 1207, 1127, 1072, 997; HRMS (ESI positive, $\mathrm{m} / \mathrm{z}$ ): found $305.0514\left([\mathrm{M}+\mathrm{Na}]^{+}\right)$, calc. for $\mathrm{C}_{14} \mathrm{H}_{19} \mathrm{BrNaO}(\mathrm{M}+\mathrm{Na})$ : 305.0517; Flash chromatography conditions: Cyclohexane/EtOAc $100 / 0 \quad$ to $90 / 10 ; \quad \mathrm{R}_{\mathrm{f}}=0.52$ (Cyclohexane/EtOAc: 95/5).

\section{1-(4-Methoxyphenyl)octan-2-one (4o)}

Compound 4o was prepared according to the general procedure using 1-(4-methoxyphenyl)octane-1,2-dione 3o (100 mg, $0.403 \mathrm{mmol})$. The title compound was obtained after flash chromatography as yellow liquid; yield $77 \%$ (72.7 mg); ${ }^{1} \mathrm{H}$ NMR (300 MHz, $\left.\mathrm{CDCl}_{3}\right) \delta 7.11(\mathrm{~d}, J=8.5$ $\mathrm{Hz}, 2 \mathrm{H}), 6.86$ (d, $J=8.6 \mathrm{~Hz}, 2 \mathrm{H}), 3.79$ (s, 3H), 3.61 (s, $2 \mathrm{H}), 2.42(\mathrm{t}, J=7.4 \mathrm{~Hz}, 2 \mathrm{H}), 1.59-1.53(\mathrm{~m}, 2 \mathrm{H}), 1.28-1.20$ $(\mathrm{m}, 6 \mathrm{H}), 0.85(\mathrm{t}, J=6.7 \mathrm{~Hz}, 3 \mathrm{H}) ;{ }^{13} \mathrm{C} \mathrm{NMR}(75 \mathrm{MHz}$, $\left.\mathrm{CDCl}_{3}\right) \delta 209.09,158.59,130.38,126.45,114.12,55.26$, $49.24,41.84,31.55,28.80,23.75,22.47,14.00$; FT-IR (neat, cm-1): 1712, 1612, 1583, 1512, 1466, 1410, 1301, 1248, 1179, 1129, 1036; HRMS (ESI positive, $\mathrm{m} / \mathrm{z}$ ): found 235.1700 $\left([\mathrm{M}+\mathrm{H}]^{+}\right)$, calc. for $\mathrm{C}_{15} \mathrm{H}_{23} \mathrm{O}_{2}(\mathrm{M}+\mathrm{H}): 235.1698$; Flash chromatography conditions: Cyclohexane/EtOAc 100/0 to $80 / 20 ; R_{\mathrm{f}}=0.60$ (Cyclohexane/EtOAc: $\left.70 / 30\right)$.

1-(4-Methoxyphenyl)pentan-2-one (4p) Compound 4p was prepared according to the general procedure using 1 (4-methoxyphenyl)pentane-1,2-dione 3p (100 mg, 0.485 mmol). The title compound was obtained after flash 
chromatography as yellow liquid; yield $95 \%(88.6 \mathrm{mg}) ;{ }^{1} \mathrm{H}$ NMR $\left(300 \mathrm{MHz}, \mathrm{CDCl}_{3}\right) \delta 7.11(\mathrm{~d}, J=8.4 \mathrm{~Hz}, 2 \mathrm{H}), 6.86$ $(\mathrm{d}, J=8.6 \mathrm{~Hz}, 2 \mathrm{H}), 3.80(\mathrm{~s}, 3 \mathrm{H}), 3.61(\mathrm{~s}, 2 \mathrm{H}), 2.41(\mathrm{t}, J=$ $7.3 \mathrm{~Hz}, 2 \mathrm{H}), 1.59-1.56(\mathrm{~m}, 2 \mathrm{H}), 0.86(\mathrm{t}, J=7.4 \mathrm{~Hz}, 3 \mathrm{H})$; ${ }^{13} \mathrm{C}$ NMR $\left(75 \mathrm{MHz}, \mathrm{CDCl}_{3}\right) \delta 208.84,158.60,130.37$, $126.43,114.12,55.25,49.25,43.73,17.21,13.65$.

\section{1-(2-Methoxyphenyl)pentan-2-one (4q)}

Compound $\mathbf{4 q}$ was prepared according to the general procedure using 1-(2-methoxyphenyl)pentane-1,2-dione $3 q$ (100 mg, $0.485 \mathrm{mmol}$ ). The title compound was obtained after flash chromatography as yellow liquid; yield $93 \%$ (86.7 mg); ${ }^{1} \mathrm{H}$ NMR $\left(300 \mathrm{MHz}, \mathrm{CDCl}_{3}\right) \delta 7.27$ $(\mathrm{td}, J=7.5,1.7 \mathrm{~Hz}, 1 \mathrm{H}), 7.15(\mathrm{dd}, J=7.4,1.6 \mathrm{~Hz}, 1 \mathrm{H})$, 6.98-6.86 (m, 2H), $3.82(\mathrm{~s}, 3 \mathrm{H}), 3.68(\mathrm{~s}, 2 \mathrm{H}), 2.43(\mathrm{t}, J=$ $7.3 \mathrm{~Hz}, 2 \mathrm{H}), 1.78-1.46(\mathrm{~m}, 2 \mathrm{H}), 0.91(\mathrm{t}, J=7.4 \mathrm{~Hz}, 3 \mathrm{H})$; ${ }^{13} \mathrm{C}$ NMR (75 MHz, $\left.\mathrm{CDCl}_{3}\right) \delta$ 209.48, 157.90, 131.71, 128.93, 124.32, 121.16, 110.99, 55.84, 45.25, 44.35, 17.80, 14.24; HRMS (ESI positive, $\mathrm{m} / \mathrm{z}$ ): found 193.1224 $\left([\mathrm{M}+\mathrm{H}]^{+}\right)$, calc. for $\mathrm{C}_{15} \mathrm{H}_{23} \mathrm{O}_{2}(\mathrm{M}+\mathrm{H})$ : 193.1229; Flash chromatography conditions: Cyclohexane/EtOAc 100/0 to $80 / 20$.

1-(4-Hydroxy-3,5-dimethoxyphenyl)octan-2-one (4r) Compound $\mathbf{4 r}$ was prepared according to the general procedure using 1-(3,4,5-trimethoxyphenyl)octane-1,2dione $3 \mathbf{r}$ (100 mg, $0.325 \mathrm{mmol})$. The title compound was obtained after flash chromatography as colorless liquid; yield 50\% (45.5 mg); ${ }^{1} \mathrm{H}$ NMR (300 MHz, $\left.\mathrm{CDCl}_{3}\right) \delta 6.41$ (s, 2H), 5.45 (br, 1H), $3.88(\mathrm{~s}, 6 \mathrm{H}), 3.58(\mathrm{~s}, 2 \mathrm{H}), 2.43$ (t, J $=7.4 \mathrm{~Hz}, 2 \mathrm{H}), 1.59-1.50(\mathrm{~m}, 2 \mathrm{H}), 1.29-1.20(\mathrm{~m}, 6 \mathrm{H}), 0.86$ $(\mathrm{t}, J=6.6 \mathrm{~Hz}, 3 \mathrm{H}) ;{ }^{13} \mathrm{C} \mathrm{NMR}\left(75 \mathrm{MHz}, \mathrm{CDCl}_{3}\right) \delta 208.94$, $147.12,133.75,125.33,106.02,56.31,50.21,41.71$, 31.56, 28.80, 23.73, 22.47, 14.00; FT-IR (neat, $\mathrm{cm}^{-1}$ ): 1706, 1614, 1518, 1462, 1429, 1367, 1331, 1245, 1217, 1115, 903; HRMS (ESI positive, $\mathrm{m} / \mathrm{z}$ ): found 303.1566 $\left([\mathrm{M}+\mathrm{Na}]^{+}\right)$, calc. for $\mathrm{C}_{16} \mathrm{H}_{24} \mathrm{NaO}_{4}(\mathrm{M}+\mathrm{Na})$ : 303.1572; Flash chromatography conditions: Cyclohexane/EtOAc 100/0 to 70/30; $\mathrm{R}_{\mathrm{f}}=0.30$ (Cyclohexane/EtOAc: $\left.70 / 30\right)$.

\section{1-(4-Hydroxyphenyl)octan-2-one (4s)}

Compound $4 \mathbf{s}$ was prepared according to the general procedure using 1-(4-hydroxyphenyl)octane-1,2-dione 3s (100 mg, $0.427 \mathrm{mmol}$ ). The title compound was obtained after flash chromatography as colorless liquid; yield $60 \%$ (56.4 mg); ${ }^{1} \mathrm{H}$ NMR $\left(300 \mathrm{MHz}, \mathrm{CDCl}_{3}\right) \delta 7.05$ (d, $J=8.3$ $\mathrm{Hz}, 2 \mathrm{H}), 6.78(\mathrm{~d}, J=8.3 \mathrm{~Hz}, 2 \mathrm{H}), 5.06(\mathrm{br}, 1 \mathrm{H}), 3.60$ (s, $2 \mathrm{H}), 2.43(\mathrm{t}, J=7.4 \mathrm{~Hz}, 2 \mathrm{H}), 1.73-1.45(\mathrm{~m}, 2 \mathrm{H}), 1.30-1.20$ $(\mathrm{m}, 6 \mathrm{H}), 0.86(\mathrm{t}, J=6.7 \mathrm{~Hz}, 3 \mathrm{H}) ;{ }^{13} \mathrm{C} \mathrm{NMR}(75 \mathrm{MHz}$, $\left.\mathrm{CDCl}_{3}\right) \delta 209.40,154.65,130.56,126.44,115.59,49.20$, 41.89, 31.53, 28.79, 23.75, 22.45, 13.99; FT-IR (neat, $\mathrm{cm}^{-}$ $\left.{ }^{1}\right): 1711,1696,1615,1595,1514,1486,1443,1364,1270$, 1223, 1107, 1065, 1014; HRMS (ESI positive, $\mathrm{m} / \mathrm{z}$ ): found $243.1358\left([\mathrm{M}+\mathrm{Na}]^{+}\right)$, calc. for $\mathrm{C}_{14} \mathrm{H}_{20} \mathrm{NaO}_{2}(\mathrm{M}+\mathrm{Na})$ : 243.1361; Flash chromatography conditions: Cyclohexane/EtOAc $70 / 30$ to $50 / 50 ; \quad \mathrm{R}_{\mathrm{f}}=0.50$ (Cyclohexane/EtOAc: 50/50).

1-(p-Tolyl)octan-2-one (4t)

Compound $4 \mathbf{t}$ was prepared according to the general procedure using 1-( $p$-tolyl)octane-1,2-dione 3t (100 mg, $0.43 \mathrm{mmol}$ ). The title compound was obtained after flash chromatography as colorless liquid; yield 97\% (91.2 mg); ${ }^{1} \mathrm{H}$ NMR $\left(300 \mathrm{MHz}, \mathrm{CDCl}_{3}\right) \delta$ 7.20-7.05 (m, 4H), 3.63 (s, $2 \mathrm{H}), 2.42(\mathrm{t}, J=7.4 \mathrm{~Hz}, 2 \mathrm{H}), 2.33(\mathrm{~s}, 3 \mathrm{H}), 1.69-1.44(\mathrm{~m}$, 2H), 1.24-1.20 (m, 4H), $0.85(\mathrm{t}, J=6.6 \mathrm{~Hz}, 3 \mathrm{H}) ;{ }^{13} \mathrm{C} \mathrm{NMR}$ $\left(75 \mathrm{MHz}, \mathrm{CDCl}_{3}\right) \delta 208.93,136.53,131.32,129.38$, $129.25,49.76,41.88,31.56,28.79,23.74,22.48,21.06$, 14.01 .

1-(p-Tolyl)pentan-2-one (4u) Compound $4 \mathbf{u}$ was prepared according to the general procedure using 1- $(p$ tolyl)pentane-1,2-dione 3u (100 mg, $0.5256 \mathrm{mmol})$. The title compound was obtained after flash chromatography as colorless liquid; yield $90 \%(83.4 \mathrm{mg}) ;{ }^{1} \mathrm{H}$ NMR (300 $\mathrm{MHz}_{\mathrm{CDCl}}$ ) $\delta$ 7.20-7.04 (m, 4H), $3.63(\mathrm{~s}, 2 \mathrm{H}), 2.42(\mathrm{t}, J$ $=7.2 \mathrm{~Hz}, 2 \mathrm{H}), 2.34(\mathrm{~s}, 3 \mathrm{H}), 1.62-1.50(\mathrm{~m}, 2 \mathrm{H}), 0.87(\mathrm{t}, J=$ $7.4 \mathrm{~Hz}, 3 \mathrm{H}) ;{ }^{13} \mathrm{C} \mathrm{NMR}\left(75 \mathrm{MHz}, \mathrm{CDCl}_{3}\right) \delta 208.74,136.53$, 131.31, 129.38, 129.24, 49.78, 43.77, 21.05, 17.20, 13.64; FT-IR (neat, $\mathrm{cm}^{-1}$ ): 1711, 1608, 1513, 1486, 1464, 1409, 1379, 1363, 1277, 1181, 1123, 1054, 1039, 1015; HRMS (ESI positive, $\mathrm{m} / \mathrm{z})$ : found $199.1100\left([\mathrm{M}+\mathrm{Na}]^{+}\right)$, calc. for $\mathrm{C}_{12} \mathrm{H}_{16} \mathrm{NaO}(\mathrm{M}+\mathrm{Na})$ : 199.1099 ; Flash chromatography conditions: Cyclohexane/EtOAc $100 / 0$ to $90 / 10 ; R_{\mathrm{f}}=0.85$ (Cyclohexane/EtOAc: 98/2).

\section{1-(4-(Methylthio)phenyl)octan-2-one (4v)}

Compound $4 \mathbf{v}$ was prepared according to the general procedure using 1-(4-(methylthio)phenyl)octane-1,2dione $3 \mathbf{v}$ (100 mg, $0.38 \mathrm{mmol})$. The title compound was obtained after flash chromatography as pink liquid; yield 96\% (90.9 mg); $\left.{ }^{1} \mathrm{H} \mathrm{NMR} \mathrm{(300} \mathrm{MHz,} \mathrm{CDCl}_{3}\right) \delta 7.22$ (d, $J$ $=8.1 \mathrm{~Hz}, 2 \mathrm{H}), 7.11(\mathrm{~d}, J=8.1 \mathrm{~Hz}, 2 \mathrm{H}), 3.63(\mathrm{~s}, 2 \mathrm{H}), 2.47$ (s, 3H), 2.43 (t, J = 7.4 Hz, 2H), 1.65-1.41 (m, 2H), 1.29$1.20(\mathrm{~m}, 6 \mathrm{H}), 0.85(\mathrm{t}, J=6.6 \mathrm{~Hz}, 3 \mathrm{H}) ;{ }^{13} \mathrm{C} \mathrm{NMR}(75 \mathrm{MHz}$, $\left.\mathrm{CDCl}_{3}\right) \delta 208.51,137.02,131.19,129.86,126.99,49.49$, 42.04, 31.55, 28.79, 23.71, 22.47, 15.96, 14.02; FT-IR (neat, $\left.\mathrm{cm}^{-1}\right): 1712,1589,1555,1493,1466,1437,1403$, 1377, 1321, 1261, 1184, 1127, 1093, 1064, 1016, 968; HRMS (ESI positive, $\mathrm{m} / \mathrm{z}$ ): found $273.1281\left([\mathrm{M}+\mathrm{Na}]^{+}\right)$, calc. for $\mathrm{C}_{15} \mathrm{H}_{22} \mathrm{NaOS}(\mathrm{M}+\mathrm{Na})$ : 273.1289; Flash chromatography conditions: Cyclohexane/EtOAc 100/0 to 80/20; $\mathrm{R}_{\mathrm{f}}=0.45$ (Cyclohexane/EtOAc: $\left.70 / 30\right)$.

\section{$\mathrm{N}$-(4-(2-Oxooctyl)phenyl)acetamide (4w)}

Compound $4 \mathbf{w}$ was prepared according to the general procedure using $\mathrm{N}$-(4-(2-oxooctanoyl)phenyl)acetamide 3w (100 mg, $0.3632 \mathrm{mmol})$. The title compound was obtained after flash chromatography as brown liquid; yield 98\% (93.0 mg); ${ }^{1} \mathrm{H}$ NMR (300 MHz, $\left.\mathrm{CDCl}_{3}\right) \delta 7.45$ (d, $J$ $=8.3 \mathrm{~Hz}, 2 \mathrm{H}), 7.14(\mathrm{~d}, J=8.3 \mathrm{~Hz}, 2 \mathrm{H}), 3.63(\mathrm{~s}, 2 \mathrm{H}), 2.43$ $(\mathrm{t}, J=7.4 \mathrm{~Hz}, 2 \mathrm{H}), 2.17(\mathrm{~s}, 3 \mathrm{H}), 1.61-1.46(\mathrm{~m}, 2 \mathrm{H}), 1.35-$ $1.02(\mathrm{~m}, 6 \mathrm{H}), 0.85(\mathrm{t}, J=6.7 \mathrm{~Hz}, 3 \mathrm{H}) ;{ }^{13} \mathrm{C} \mathrm{NMR}(75 \mathrm{MHz}$, $\left.\mathrm{CDCl}_{3}\right) \delta 209.05,168.64,136.94,130.06,129.87,120.21$, 49.41, 42.11, 31.53, 28.77, 24.44, 23.72, 22.45, 14.00; FTIR (neat, $\mathrm{cm}^{-1}$ ): 1712, 1668, 1603, 1538, 1514, 1467, 1412, 1371, 1319, 1264, 1178, 1128, 1066; HRMS (ESI positive, $m / z)$ : found $262.1802\left([\mathrm{M}+\mathrm{H}]^{+}\right)$, calc. for $\mathrm{C}_{16} \mathrm{H}_{23} \mathrm{NO}_{2}$ $(\mathrm{M}+\mathrm{H})$ : 262.1807; Flash chromatography conditions: Cyclohexane/EtOAc $70 / 0$ to $50 / 50 ; \quad \mathrm{R}_{\mathrm{f}}=0.55$ (Cyclohexane/EtOAc: 50/50).

\section{1-(Naphthalen-2-yl)octan-2-one (4x)}

Compound $4 \mathbf{x}$ was prepared according to the general procedure using 1-(naphthalen-2-yl)octane-1,2-dione $\mathbf{3 x}$ $(100 \mathrm{mg}, 0.37 \mathrm{mmol})$. The title compound was obtained after flash chromatography as yellow liquid; yield $92 \%$ $(87.2 \mathrm{mg}) ;{ }^{1} \mathrm{H}$ NMR (400 MHz, $\left.\mathrm{CDCl}_{3}\right) \delta$ 7.75-7.61 (m, $3 \mathrm{H}), 7.54$ (s, 1H), 7.40-7.30 (m, 2H), 7.20 (d, $J=8.4 \mathrm{~Hz}$, $1 \mathrm{H}), 3.69$ (s, 2H), 2.34 (t, $J=7.4 \mathrm{~Hz}, 2 \mathrm{H}), 1.50-1.40$ (m, $2 \mathrm{H}), 1.17-1.03(\mathrm{~m}, 6 \mathrm{H}), 0.73(\mathrm{t}, J=6.7 \mathrm{~Hz}, 3 \mathrm{H}) ;{ }^{13} \mathrm{C} \mathrm{NMR}$ $\left(101 \mathrm{MHz}, \mathrm{CDCl}_{3}\right) \delta 208.49,133.62,132.46,132.01$, 
$128.35,128.10,127.69,127.62,127.52,126.19,125.77$, $50.29,42.09,31.58,28.81,23.75,22.48,14.01$; FT-IR (neat, $\mathrm{cm}^{-1}$ ): 1713, 1632, 1600, 1509, 1466, 1406, 1260, 1126, 1069, 1017, 959, 908; HRMS (ESI positive, $\mathrm{m} / \mathrm{z}$ ): found $255.1749\left([\mathrm{M}+\mathrm{H}]^{+}\right)$, calc. for $\mathrm{C}_{18} \mathrm{H}_{23} \mathrm{O}(\mathrm{M}+\mathrm{H})$ : 255.1749; Flash chromatography conditions: Cyclohexane/EtOAc $100 / 0 \quad$ to $98 / 2 ; \quad \mathrm{R}_{\mathrm{f}}=0.70$ (Cyclohexane/EtOAc: 95/5).

\section{6-Hydroxy-1-(4-methoxyphenyl)hexan-2-one (4y)}

Compound $4 \mathbf{y}$ was prepared according to the general procedure using 6-hydroxy-1-(4-methoxyphenyl)hexane1,2-dione 3y (100 mg, $0.42 \mathrm{mmol})$. The title compound was obtained after flash chromatography as colorless liquid; yield $80 \%$ (75.3 mg); ${ }^{1} \mathrm{H} \mathrm{NMR}\left(300 \mathrm{MHz}, \mathrm{CDCl}_{3}\right)$ $\delta 7.11(\mathrm{~d}, J=8.5 \mathrm{~Hz}, 2 \mathrm{H}), 6.86(\mathrm{~d}, J=8.6 \mathrm{~Hz}, 2 \mathrm{H}), 3.79$ $(\mathrm{s}, 3 \mathrm{H}), 3.61(\mathrm{~s}, 2 \mathrm{H}), 3.11(\mathrm{t}, J=6.7 \mathrm{~Hz}, 2 \mathrm{H}), 2.45(\mathrm{t}, J=$ $7.0 \mathrm{~Hz}, 2 \mathrm{H}), 1.99-1.49(\mathrm{~m}, 4 \mathrm{H}) ;{ }^{13} \mathrm{C} \mathrm{NMR}(75 \mathrm{MHz}$, $\left.\mathrm{CDCl}_{3}\right) \delta 208.06,158.70,130.36,126.16,114.22,55.28$, 49.30, 40.30, 32.72, 24.55, 6.08; FT-IR (neat, $\left.\mathrm{cm}^{-1}\right): 1710$, 1611, 1583, 1511, 1462, 1406, 1301, 1245, 1177, 1112, 1032; HRMS (ESI positive, $\mathrm{m} / \mathrm{z}$ ): found 223.1340 $\left([\mathrm{M}+\mathrm{H}]^{+}\right)$, calc. for $\mathrm{C}_{13} \mathrm{H}_{19} \mathrm{O}_{3}(\mathrm{M}+\mathrm{H})$ : 223.1334; Flash chromatography conditions: Cyclohexane/EtOAc 70/30 to 50/50; $\mathrm{R}_{\mathrm{f}}=0.45$ (Cyclohexane/EtOAc: 70/30).

\section{6-Methoxy-1-(4-methoxyphenyl)hexan-2-one (4z)}

Compound $\mathbf{4 z}$ was prepared according to the general procedure using 6-methoxy-1-(4-methoxyphenyl)hexane1,2-dione 3z (100 mg, $0.40 \mathrm{mmol})$. The title compound was obtained after flash chromatography as yellow liquid; yield $78 \%(73.6 \mathrm{mg}) ;{ }^{1} \mathrm{H}$ NMR $\left(400 \mathrm{MHz}, \mathrm{CDCl}_{3}\right) \delta 7.03$ $(\mathrm{d}, J=8.5 \mathrm{~Hz}, 2 \mathrm{H}), 6.78(\mathrm{~d}, J=8.5 \mathrm{~Hz}, 2 \mathrm{H}), 3.70(\mathrm{~s}, 3 \mathrm{H})$, $3.53(\mathrm{~s}, 2 \mathrm{H}), 3.33-2.86(\mathrm{~m}, 5 \mathrm{H}), 2.38(\mathrm{t}, J=7.2 \mathrm{~Hz}, 2 \mathrm{H})$, $1.55-1.48(\mathrm{~m}, 4 \mathrm{H}) ;{ }^{13} \mathrm{C} \mathrm{NMR}\left(101 \mathrm{MHz}, \mathrm{CDCl}_{3}\right) \delta 208.58$, $158.69,130.42,126.44,114.19,72.43,58.52,55.28$, 49.25, 41.47, 29.01, 20.50; FT-IR (neat, $\mathrm{cm}^{-1}$ ): 1713, 1613, 1598, 1573, 1513, 1464, 1408, 1363, 1301, 1248, 1178, 1119, 1080, 1036; HRMS (ESI positive, $\mathrm{m} / \mathrm{z}$ ): found $259.1310\left([\mathrm{M}+\mathrm{Na}]^{+}\right)$, calc. for $\mathrm{C}_{13} \mathrm{H}_{20} \mathrm{O}_{3} \mathrm{Na}(\mathrm{M}+\mathrm{Na})$ : 259.1310; Flash chromatography conditions: Cyclohexane/EtOAc $90 / 10$ to $70 / 30 ; \quad \mathrm{R}_{\mathrm{f}}=0.60$ (Cyclohexane/EtOAc: 70/30).

\section{1-(Quinolin-6-yl)octan-2-one (4za)}

Compound 4za was prepared according to the general procedure using 1-(quinolin-6-yl)octane-1,2-dione 3za (100 mg, $0.37 \mathrm{mmol}$ ). The title compound was obtained after flash chromatography as yellow liquid; yield $65 \%$ (61.6 mg); ${ }^{1} \mathrm{H}$ NMR (300 MHz, $\left.\mathrm{CDCl}_{3}\right) \delta 8.89(\mathrm{~d}, J=4.2$ $\mathrm{Hz}, 1 \mathrm{H}), 8.29-7.92(\mathrm{~m}, 2 \mathrm{H}), 7.64$ (s, 1H), 7.55 (d, $J=8.6$, $1 \mathrm{H}), 7.50-7.40(\mathrm{~m}, 1 \mathrm{H}), 3.87(\mathrm{~s}, 2 \mathrm{H}), 2.49(\mathrm{t}, \mathrm{J}=7.4 \mathrm{~Hz}$, $2 \mathrm{H}), 1.95-1.42(\mathrm{~m}, 2 \mathrm{H}), 1.28-1.22(\mathrm{~m}, 6 \mathrm{H}), 0.83(\mathrm{t}, J=6.6$ $\mathrm{Hz}, 3 \mathrm{H}) ;{ }^{13} \mathrm{C} \mathrm{NMR}\left(75 \mathrm{MHz}, \mathrm{CDCl}_{3}\right) \delta 208.01,150.28$, $147.41,135.73,132.80,131.22,129.78,128.30,127.90$, 121.33, 49.79, 42.39, 31.52, 28.77, 23.70, 22.43, 13.96; FT-IR (neat, $\mathrm{cm}^{-1}$ ): 1712, 1622, 1595, 1572, 1501, 1466, 1406, 1379, 1366, 1325, 1119, 1065, 1032, 957; HRMS (ESI positive, $\mathrm{m} / z)$ : found $256.1707\left([\mathrm{M}+\mathrm{H}]^{+}\right)$, calc. for $\mathrm{C}_{17} \mathrm{H}_{22} \mathrm{NO}(\mathrm{M}+\mathrm{H}): 256.1701$; Flash chromatography conditions: Cyclohexane/EtOAc $100 / 0$ to $70 / 30 ; \mathrm{R}_{\mathrm{f}}=0.65$ (Cyclohexane/EtOAc: 50/50).

(2R,3R,4S,5R,6S)-2-(acetoxymethyl)-6-((4-(2oxooctyl)phenyl)thio)tetrahydro-2H-pyran-3,4,5-triyl triacetate $(4 \mathrm{zb})$
Compound 4zb was prepared according to the general procedure using (2R,3R,4S,5R,6S)-2-(acetoxymethyl)-6((4-(2-oxooctanoyl)phenyl)thio)tetrahydro-2H-pyran-

3,4,5-triyl triacetate 3zb (100 mg, $0.1722 \mathrm{mmol}$ ). The title compound was obtained after flash chromatography as yellow liquid; yield $50 \%(48.8 \mathrm{mg}) ;[\alpha]_{\mathrm{D}}{ }^{25}-11(\mathrm{c}, 0.55 \mathrm{in}$ $\mathrm{CH}_{2} \mathrm{Cl}_{2}$ ); ${ }^{1} \mathrm{H}$ NMR $\left(400 \mathrm{MHz}, \mathrm{CDCl}_{3}\right) \delta 7.45(\mathrm{~d}, J=8.1$ $\mathrm{Hz}, 2 \mathrm{H}), 7.14$ (d, $J=8.1 \mathrm{~Hz}, 2 \mathrm{H}), 5.22(\mathrm{t}, J=9.3 \mathrm{~Hz}, 1 \mathrm{H})$, $5.04(\mathrm{t}, J=9.8 \mathrm{~Hz}, 1 \mathrm{H}), 4.97(\mathrm{t}, J=9.7 \mathrm{~Hz}, 1 \mathrm{H}), 4.69$ (d, $J=10.1 \mathrm{~Hz}, 1 \mathrm{H}), 4.29-4.12(\mathrm{~m}, 2 \mathrm{H}), 3.75-3.70(\mathrm{~m}, 1 \mathrm{H})$, $3.68(\mathrm{~s}, 1 \mathrm{H}), 2.46(\mathrm{t}, J=7.4 \mathrm{~Hz}, 2 \mathrm{H}), 2.08(\mathrm{~s}, 6 \mathrm{H}), 2.02(\mathrm{~s}$, $3 \mathrm{H}), 1.99$ (s, 3H), 1.58-1.54 (m, 2H), 1.28-1.24 (m, 6H), $0.86(\mathrm{t}, J=6.8 \mathrm{~Hz}, 3 \mathrm{H}) .{ }^{13} \mathrm{C}$ NMR $\left(101 \mathrm{MHz}, \mathrm{CDCl}_{3}\right) \delta$ 207.99, 170.67, 170.27, 169.50, 169.36, 134.95, 133.51, 130.42, 130.17, 86.01, 75.98, 74.12, 70.12, 68.38, 62.29, 49.57, 42.53, 31.69, 28.93, 23.85, 22.60, 20.87, 20.71, 14.14; FT-IR (neat, $\mathrm{cm}^{-1}$ ): 2930, 1756, 1713, 1603, 1367, 1248, 1214, 1037, 915; HRMS (ESI positive, $m / z$ ): found $589.2083\left([\mathrm{M}+\mathrm{Na}]^{+}\right)$, calc. for $\mathrm{C}_{28} \mathrm{H}_{38} \mathrm{O}_{10} \mathrm{SNa}(\mathrm{M}+\mathrm{Na})$ : 589.2078; Flash chromatography conditions: Cyclohexane/EtOAc $70 / 30$ to $50 / 50 ; \quad \mathrm{R}_{\mathrm{f}}=0.30$ (Cyclohexane/EtOAc: 50/50).

4-(1-Hydroxy-2-oxooctyl)benzaldehyde (5)

Compound $\mathbf{5}$ was prepared according to the general procedure using 4-(2-oxooctanoyl)benzaldehyde $\mathbf{3 h}$ (100 $\mathrm{mg}, 0.41 \mathrm{mmol})$. The title compound was obtained after flash chromatography as yellow liquid; yield $59 \% ;{ }^{1} \mathrm{H}$ NMR $\left(300 \mathrm{MHz}, \mathrm{CDCl}_{3} \delta 10.03(\mathrm{~s}, 1 \mathrm{H}), 7.91\right.$ (d, $J=8.1$ $\mathrm{Hz}, 2 \mathrm{H}), 7.52$ (d, J = 8.0 Hz, 2H), $5.16(\mathrm{~s}, 1 \mathrm{H}), 2.49-2.18$ $(\mathrm{m}, 2 \mathrm{H}), 1.48-0.99(\mathrm{~m}, 8 \mathrm{H}), 0.82(\mathrm{t}, J=6.9 \mathrm{~Hz}, 3 \mathrm{H}) ;{ }^{13} \mathrm{C}$ $\mathrm{NMR}\left(75 \mathrm{MHz}, \mathrm{CDCl}_{3}\right) \delta 208.46,191.61,144.62,136.53$, 130.27, 128.00, 79.37, 37.91, 31.31, 28.58, 23.55, 22.35, 13.93, FT-IR (neat, $\mathrm{cm}^{-1}$ ): 2958, 2929, 2855, 1703, 1607, 1579, 1467, 1363, 1306, 1209, 1167, 904; HRMS (ESI positive, $m / z)$ : found $271.1315\left([\mathrm{M}+\mathrm{Na}]^{+}\right)$, calc. for $\mathrm{C}_{15} \mathrm{H}_{20} \mathrm{NaO}_{3}$ (M+Na): 271.1310; Flash chromatography conditions: Cyclohexane/EtOAc $100 / 0$ to $90 / 10 ; R_{\mathrm{f}}=0.50$ (Cyclohexane/EtOAc: 9/1).

\section{Ethyl 2-(4-methoxyphenyl)acetate (9a)}

Compound 9a was prepared according to the general procedure using ethyl 2-(4-methoxyphenyl)-2-oxoacetate 6a $(100 \mathrm{mg}, 0.48 \mathrm{mmol}) .{ }^{1} \mathrm{H}$ NMR $\left(300 \mathrm{MHz}, \mathrm{CDCl}_{3}\right) \delta$ $7.20(\mathrm{~d}, J=8.5 \mathrm{~Hz}, 2 \mathrm{H}), 6.86(\mathrm{~d}, J=8.5 \mathrm{~Hz}, 2 \mathrm{H}), 4.15(\mathrm{q}$, $J=7.1 \mathrm{~Hz}, 2 \mathrm{H}), 3.79$ (s, 3H), 3.55 (s, 2H), $1.25(\mathrm{t}, J=7.1$ $\mathrm{Hz}, 3 \mathrm{H}) ;{ }^{13} \mathrm{C} \mathrm{NMR}\left(75 \mathrm{MHz}, \mathrm{CDCl}_{3}\right) \delta 171.92,158.66$, $130.23,126.24,113.97,60.75,55.23,40.52,14.18$.

Ethyl 2-(2-methoxyphenyl)acetate (9b)

Compound 9b was prepared according to the general procedure using ethyl 2-(2-methoxyphenyl)-2-oxoacetate 6b (100 mg, $0.48 \mathrm{mmol}) .{ }^{1} \mathrm{H}$ NMR (300 MHz, $\left.\mathrm{CDCl}_{3}\right) \delta$ 7.33-7.02 (m, 2H), 6.89-6.75 (m, 2H), $4.08(\mathrm{q}, J=7.1 \mathrm{~Hz}$, 2H), 3.73 (s, 3H), 3.54 (s, 2H), 1.17 (t, $J=7.1 \mathrm{~Hz}, 3 \mathrm{H})$; ${ }^{13} \mathrm{C}$ NMR $\left(75 \mathrm{MHz}, \mathrm{CDCl}_{3}\right) \delta 171.86,157.54,130.82$, $128.46,123.23,120.49,110.48$, 60.56, 55.41, 36.01, 14.23 .

Ethyl 2-(4-(methylthio)phenyl)acetate (9c) Compound 9c was prepared according to the general procedure using ethyl 2-(4-(methylthio)phenyl)-2-oxoacetate 6c (100 mg, $0.45 \mathrm{mmol}) .{ }^{1} \mathrm{H}$ NMR $\left(300 \mathrm{MHz}, \mathrm{CDCl}_{3}\right) \delta 7.25-7.20(\mathrm{~m}$, $4 \mathrm{H}), 4.14(\mathrm{q}, J=7.1 \mathrm{~Hz}, 2 \mathrm{H}), 3.56(\mathrm{~s}, 2 \mathrm{H}), 2.47(\mathrm{~s}, 3 \mathrm{H})$, $1.25(\mathrm{t}, J=7.1 \mathrm{~Hz}, 3 \mathrm{H}) ;{ }^{13} \mathrm{C} \mathrm{NMR}\left(75 \mathrm{MHz}, \mathrm{CDCl}_{3}\right) \delta$ 171.49 , 137.12, 131.01, 129.70, 126.92, 60.88, 40.85, 
$15.99,14.18$.

Ethyl 2-(3-chloro-4-(methylthio)phenyl)acetate (9d) Compound 9d was prepared according to the general procedure using ethyl 2-(3-chloro-4-(methylthio)phenyl)2-oxoacetate 6d (100 mg, $0.386 \mathrm{mmol}) .{ }^{1} \mathrm{H}$ NMR $(300$ $\left.\mathrm{MHz} \mathrm{CDCl}_{3}\right) \delta 7.28(\mathrm{~s}, 1 \mathrm{H}), 7.17(\mathrm{~d}, J=8.2 \mathrm{~Hz}, 1 \mathrm{H}), 7.11$ $(\mathrm{d}, J=8.1 \mathrm{~Hz}, 1 \mathrm{H}), 4.15(\mathrm{q}, J=7.1 \mathrm{~Hz}, 2 \mathrm{H}), 3.54(\mathrm{~s}, 2 \mathrm{H})$, $2.46(\mathrm{~s}, 3 \mathrm{H}), 1.25$ (t, $J=7.1 \mathrm{~Hz}, 3 \mathrm{H}) ;{ }^{13} \mathrm{C}$ NMR $(75 \mathrm{MHz}$, $\left.\mathrm{CDCl}_{3}\right) \delta 171.00,136.40,131.81,130.14,128.16,125.81$, 61.08, 40.39, 15.27, 14.17; FT-IR (neat, $\mathrm{cm}^{-1}$ ): 1733, 1551, 1470, 1435, 1397, 1367, 1335, 1263, 1175, 1156, 1125, 1095, 1033, 903; HRMS (ESI positive, $\mathrm{m} / z$ ): found $267.0214\left([\mathrm{M}+\mathrm{Na}]^{+}\right)$, calc. for $\mathrm{C}_{11} \mathrm{H}_{13} \mathrm{O}_{2} \mathrm{NaSCl}(\mathrm{M}+\mathrm{Na})$ : 267.0222 .

2-(4-(methylthio)phenyl)acetic acid (10a) Compound 10a was prepared according to the general procedure using 2-(4-(methylthio)phenyl)-2-oxoacetic acid 7a (100 mg, $0.386 \mathrm{mmol}$ ). The title compound was obtained after flash chromatography as white solid; yield $91 \%$ (67.6 mg); mp: 98.5-99.4 ${ }^{\circ} \mathrm{C} ;{ }^{1} \mathrm{H}$ NMR $\left(300 \mathrm{MHz}, \mathrm{CDCl}_{3}\right) \delta 10.81$ (broad, $1 \mathrm{H}), 7.68-6.37(\mathrm{~m}, 4 \mathrm{H}), 3.52(\mathrm{~s}, 2 \mathrm{H}), 2.38(\mathrm{~s}, 3 \mathrm{H}) ;{ }^{13} \mathrm{C}$ $\mathrm{NMR}\left(75 \mathrm{MHz}, \mathrm{CDCl}_{3}\right) \delta 177.95,137.64,130.00,129.83$, 126.90, 40.49, 15.90; FT-IR (neat, $\mathrm{cm}^{-1}$ ): 2920, 2742, 1712 , 1680, 1605, 1495, 1425, 1406, 1348, 1257, 1202, $1115,1089,1016,971,907$; found $205.0307\left([\mathrm{M}+\mathrm{Na}]^{+}\right)$, calc. For $\mathrm{C}_{9} \mathrm{H}_{10} \mathrm{NaO}_{2} \mathrm{~S} \quad(\mathrm{M}+\mathrm{Na})$ 205.0299. Flash chromatography conditions: Cyclohexane/EtOAc 70/30 to 50/50; $\mathrm{R}_{\mathrm{f}}=0.45$ (Cyclohexane/EtOAc: $\left.70 / 30\right)$.

2-(4-methoxyphenyl)acetic acid (10b) Compound 10b was prepared according to the general procedure using 2(4-(methyoxyphenyl)phenyl)-2-oxoacetic acid 7a (100 $\mathrm{mg}, 0.5551 \mathrm{mmol})$. The title compound was obtained after flash chromatography as white solid; yield $90 \%(83.0 \mathrm{mg})$; ${ }^{1} \mathrm{H}$ NMR $\left(300 \mathrm{MHz}, \mathrm{CDCl}_{3}\right) \delta 7.20(\mathrm{~d}, J=8.5 \mathrm{~Hz}, 2 \mathrm{H})$, $6.87(\mathrm{~d}, J=8.5 \mathrm{~Hz}, 2 \mathrm{H}), 3.80(\mathrm{~s}, 3 \mathrm{H}), 3.60(\mathrm{~s}, 2 \mathrm{H}) ;{ }^{13} \mathrm{C}$ NMR $\left(75 \mathrm{MHz}, \mathrm{CDCl}_{3}\right) \delta 177.66,158.86,130.40,125.39$, 114.08, 55.26, 40.12.

\section{Ethyl-2-(4-methoxyphenyl)-2-(2-tosylhydrazono)}

acetate (8)

A solution of compound $\mathbf{6 a}(1 \mathrm{mmol})$ in $\mathrm{EtOH}(3 \mathrm{~mL})$ was added to a stirred mixture of $p$-toluenesulfonyl hydrazide $(1.1 \mathrm{mmol})$ in ethanol $(3 \mathrm{~mL})$ containing $\mathrm{H}_{2} \mathrm{SO}_{4}(0.015$ mmol). The reaction was refluxed at $85^{\circ} \mathrm{C}$ overnight then cooled to room temperature. The white precipitated solid was filtered, washed with cold $\mathrm{MeOH}$ and cold hexane, and then dried under reduced pressure to give crude. The pure compound was obtained after flash chromatography as colorless liquid. Yield $70 \%$ (263.5 mg). ${ }^{1} \mathrm{H}$ NMR (300 $\left.\mathrm{MHz}, \mathrm{CDCl}_{3}\right) \delta 11.29(\mathrm{br}, 1 \mathrm{H}), 7.87(\mathrm{~d}, J=7.5 \mathrm{~Hz}, 2 \mathrm{H})$, 7.49 (d, $J=8.7 \mathrm{~Hz}, 2 \mathrm{H}), 7.31(\mathrm{~d}, J=7.5 \mathrm{~Hz}, 2 \mathrm{H}), 6.86(\mathrm{~d}$, $J=8.7 \mathrm{~Hz}, 2 \mathrm{H}), 4.35(\mathrm{q}, J=7.1 \mathrm{~Hz}, 2 \mathrm{H}), 3.82(\mathrm{~s}, 3 \mathrm{H}), 2.41$ $(\mathrm{s}, 3 \mathrm{H}), 1.34(\mathrm{t}, J=7.1 \mathrm{~Hz}, 3 \mathrm{H}) ;{ }^{13} \mathrm{C} \mathrm{NMR}(75 \mathrm{MHz}$, $\left.\mathrm{CDCl}_{3}\right) \delta 162.21,160.63,144.28,138.50,135.57,129.90$, $129.68,127.94,126.45,113.51,62.34,55.31,21.60$, 14.01; FT-IR (neat, $\mathrm{cm}^{-1}$ ): 1731, 1690, 1608, 1513, 1465, 1369, 1347, 1303, 1292, 1255, 1228, 1167, 1123, 1084, 1035, 1016, 989, 920; HRMS (ESI positive, $\mathrm{m} / \mathrm{z}$ ): found $399.0984\left([\mathrm{M}+\mathrm{Na}]^{+}\right)$, calc. for $\mathrm{C}_{18} \mathrm{H}_{20} \mathrm{O}_{5} \mathrm{~N}_{2} \mathrm{NaS}(\mathrm{M}+\mathrm{Na})$ : 399.0991. Flash chromatography conditions: Cyclohexane/EtOAc $90 / 10 \quad$ to $70 / 30 ; \quad \mathrm{R}_{\mathrm{f}}=0.45$ (Cyclohexane/EtOAc: 80/20).

\section{Acknowledgments}

Authors gratefully acknowledge support of this project by CNRS, Univ. Paris-Sud, and by La Ligue Nationale Contre le Cancer through an Equipe Labellisée 2014 grant. LZY and GZ thank the Chinese Scholarship Council for Ph.D. fundings. Our laboratory is a member of the laboratory of excellence LERMIT supported by a grant from ANR (ANR10-LABX-33).

\section{References}

[1] G. A. Olah, S. C. Narang, B. G. B. Gupta, R. Malhotra, J. Org. Chem., 1979, 44, 1247-1251.

[2] G. A. Olah, B. G. B. Gupta, S. C. Narang, Synthesis, 1977, 583-584.

[3] L. Z. Yuan, D. Renko, I. Khelifi, O. Provot, J. D. Brion, A. Hamze, M. Alami, Org. Lett., 2016, 18, 3238-3241.

[4] A similar observation was reported in $\mathrm{CH}_{3} \mathrm{CN}$, see: $\mathrm{G}$. A. Olah, S. C. Narang, Tetrahedron, 1982, 38, 22252277.

[5] G. Xu, L. Feng, P. Song, F. Xu, A. Li, Y. Wang, Y. Shen, X. Wu, Q. Luo, X. Wu, Y. Sun, X. Wu, Q. Xu, Int. Immunophamacol., 2016, 38, 175-185.

[6] See for examples: a) M. Zhao, B. Lu, G. Ding, K. Ren, X. Xiea, Z. Zhang, Org. Biomol. Chem., 2016, 14 2723-2730. b) B. Rao, J. Tang, X. Zeng, Org. Lett., 2016, 18, 1678-1681. c) M. Islam, H. Tomiyasu, T. Matsumoto, J. Tanaka, S. Rahman, P. E. Georghiou, C. Redshawd, T. Yamato, Org. Biomol. Chem., 2015, 13, 9055-9064.

[7] L. M. Stephenson, L. C. Falk, J. Org. Chem., 1976, 41, 2928. b) Y. Kamochi, T. Kudo, T. Masuda, A. Takadate, Chem. Pharm. Bull., 2005, 53, 1017-1020.

[8] When the deoxygenation of benzil (1,2diphenylethanedione) was achieved in $\mathrm{CH}_{2} \mathrm{Cl}_{2}$, after 3 days of reaction, a complex mixture containing benzil $(6 \%)$, benzoin (2-hydroxy-1,2-diphenylethan-1-one) $(13 \%)$, deoxybenzoin $(11 \%)$ and 2,2'-oxybis(1,2diphenylethan-1-one) (43\%) and other unidentified by-products was obtained.

[9] a) C. Mousset, O. Provot, A. Hamze, J. Bignon, J. D. Brion, M. Alami, Tetrahedron, 2008, 64, 4287-4294 b) C. Mousset, A. Giraud, O. Provot, A. Hamze, J. Bignon, J.M. Liu, S. Thoret, J. Dubois, J. D. Brion, M. Alami, Bioorg. Med. Chem. Lett., 2008, 18, 32663271. c) A. Giraud, O. Provot, J.F. Peyrat, M. Alami, J. D. Brion, Tetrahedron 2006, 62, 7667-7673.

[10] For a review concerning the oxidation of diarylalkynes into benzils, see: L.Z. Yuan, A. Hamze, M. Alami, O. Provot, Synthesis, 2017, 49, 504-525. 
[11] In the presence of 10 equivalents of TMSCl/ $\mathrm{NaI}$ and after $6 \mathrm{~h}$ of stirring at $\mathrm{rt}$ in $\mathrm{CH}_{2} \mathrm{Cl}_{2}, 3 \mathbf{h}$ was partially reduced and transformed into 4-(1-hydroxy-2oxooctyl)benzaldehyde 5 (59\%). Increasing the reaction time or the number of equivalents of $\mathrm{TMSCl} / \mathrm{NaI}$ was unsuccessful and led to a mixture of non-identified by-products.

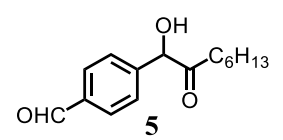

[12] C. D. Hurd, H. E. Winberg, J. Am. Chem. Soc., 1942, 64, 2085-2086.

[13] A. Bruneau, M. Roche, A. Hamze, J. D. Brion, M. Alami, S. Messaoudi, Chem. Eur. J., 2015, 21, 83758379.

[14] R. Sarabu, F. T. Bizzarro, W. L. Corbett, M. T. Dvorozniak, W. Geng, J. F. Grippo, N.-E; Haynes, S. Hutchings, L. Garofalo, K. R. Guertin, D. W. Hiliard, M. Kabat, R. F. Kester, W. Ka, Z. Liang, P. E. Mahaney, L. Marcus, F. M. Matschinsky, D. Moore, J. Racha, R. Radinov, Y. Ren, L. Qi, M. Pignatello, C. L.
Spence, T. Steele, J. Tengi, J. Grimsby, J. Med. Chem., 2012, 55, 7021-7036.

[15] J. M. Zimbron, M. Seeger-Weibel, H. Hirt, F. Gallou, Synthesis, 2008, 8, 1221-1226.

[16] L. Ackermann, L. T. Kaspar, J. Org. Chem., 2007, 72, 6149-6153.

[17] A. Schäfer, A. Wellner, R. Gust, ChemMedChem, 2011, 6, 794-803.

[18] D. F. Taber, W. Tian, J. Org. Chem., 2007, 72, 32073210 .

[19] H. Sadeghiana, N. Attaranb, Z. Jafarib, M. Saberic, M. Pordela, M. Riazib, Bioorg. Med. Chem., 2009, 17, 2327-2335.

[20] N. Ríos-Lombardía, E. Busto, E. García-Urdiales, V. Gotor-Fernández, V. Gotor, J. Org. Chem., 2009, 74, 2571-2574.

[21] B. Song, F. Rudolphi, T. Himmler, L. Gooßen, $A d v$. Synth. Catal., 2011, 353, 1565-1574.

[22] L. Shen, X. Yang, B. Yang, Q. He, Y. Hu, Eur. J. Med. Chem., 2010, 45, 11-18. 


\section{FULL PAPER}

Chlorotrimethylsilane and Sodium Iodide: A Useful Combination for the Regioselective Deoxygenation of Arylalkyl- $\alpha$-Diketones

Adv. Synth. Catal. Year, Volume, Page Page

Ling-Zhi Yuan, Guangkuan Zhao, Abdallah Hamze, Mouad Alami* and Olivier Provot*

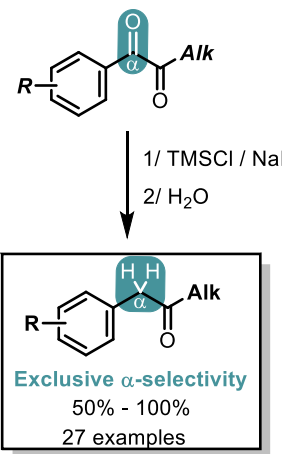

$\boldsymbol{A} \boldsymbol{k} \boldsymbol{k}=\mathrm{Me}, \mathrm{C}_{3} \mathrm{H}_{7}, \mathrm{C}_{6} \mathrm{H}_{13},\left(\mathrm{CH}_{2}\right)_{4} \mathrm{OH},\left(\mathrm{CH}_{2}\right)_{4} \mathrm{OMe}$ $\boldsymbol{R}=\mathrm{NO}_{2}, \mathrm{COMe}, \mathrm{Br}, \mathrm{Cl}, \mathrm{I}, \mathrm{CF}_{3}, \mathrm{CN}, \mathrm{CO}_{2} \mathrm{Me}, \mathrm{OMe}$ $\mathrm{Me}, \mathrm{SMe}, \mathrm{NHAc}, \mathrm{OH}, \mathrm{S}$-sugar,... 